\title{
Harnessing the Immune System to Fight Multiple Myeloma
}

\author{
Jakub Krejcik 1,2,3, Mike Bogetofte Barnkob ${ }^{1,4}$ (), Charlotte Guldborg Nyvold 1,3,5, Thomas Stauffer Larsen 1,2,3, \\ Torben Barington $1,4(1)$ and Niels Abildgaard ${ }^{1,2,3, *}$
}

1 Centre for Cellular Immunotherapy of Haematological Cancer Odense (CITCO), Odense University Hospital, 5000 Odense, Denmark; jakub.krejcik@rsyd.dk (J.K.); Mike.Bogetofte.Barnkob@rsyd.dk (M.B.B.); Charlotte.Guldborg.Nyvold@rsyd.dk (C.G.N.); Thomas.Stauffer.Larsen@rsyd.dk (T.S.L.); Torben.Barington@rsyd.dk (T.B.)

2 Department of Haematology, Odense University Hospital, 5000 Odense, Denmark

3 Haematology Research Unit, Department of Clinical Research, University of Southern Denmark, 5000 Odense, Denmark

4 Department of Clinical Immunology, Odense University Hospital, 5000 Odense, Denmark

5 Haematology-Pathology Research Laboratory, Research Unit for Haematology and Research Unit for Pathology, University of Southern Denmark and Odense University Hospital, 5000 Odense, Denmark

* Correspondence: niels.abildgaard@rsyd.dk

check for updates

Citation: Krejcik, J.; Barnkob, M.B.; Nyvold, C.G.; Larsen, T.S.; Barington, T.; Abildgaard, N. Harnessing the Immune System to Fight Multiple Myeloma. Cancers 2021, 13, 4546. https://doi.org/10.3390/ cancers 13184546

Academic Editor: Gabor Mikala

Received: 21 July 2021

Accepted: 6 September 2021

Published: 10 September 2021

Publisher's Note: MDPI stays neutral with regard to jurisdictional claims in published maps and institutional affiliations.

Copyright: (c) 2021 by the authors. Licensee MDPI, Basel, Switzerland. This article is an open access article distributed under the terms and conditions of the Creative Commons Attribution (CC BY) license (https:/ / creativecommons.org/licenses/by/ $4.0 /)$.
Simple Summary: Multiple myeloma treatment has developed enormously within the last two decades. Most recently immunotherapies have been introduced. Monoclonal antibodies targeting the plasma cell surface marker CD38, daratumumab and isatuximab, have revolutionized the standard of care treatment, and CAR T-cell therapy has been FDA-approved for the treatment of relapsed, refractory multiple myeloma. However, many other immunotherapeutic principles are under current clinical testing. It is well described that immune dysfunction is present in multiple myeloma and worsens by disease progression and may even be involved in the transformation to malignancy from benign precursor states, smoldering myeloma, and MGUS. Thus, attempts to revive and engage the innate and adaptive immune system are appealing. The ultimate goal is the cure or prevention of cancer development. In this review, the reader receives basic information on the immune dysfunction in multiple myeloma, a thorough summary of the ways to harness the immune system in treatment, the current status of clinical development, and future aspects.

Abstract: Multiple myeloma (MM) is a heterogeneous plasma cell malignancy differing substantially in clinical behavior, prognosis, and response to treatment. With the advent of novel therapies, many patients achieve long-lasting remissions, but some experience aggressive and treatment refractory relapses. So far, MM is considered incurable. Myeloma pathogenesis can broadly be explained by two interacting mechanisms, intraclonal evolution of cancer cells and development of an immunosuppressive tumor microenvironment. Failures in isotype class switching and somatic hypermutations result in the neoplastic transformation typical of MM and other B cell malignancies. Interestingly, although genetic alterations occur and evolve over time, they are also present in premalignant stages, which never progress to MM, suggesting that genetic mutations are necessary but not sufficient for myeloma transformation. Changes in composition and function of the immune cells are associated with loss of effective immune surveillance, which might represent another mechanism driving malignant transformation. During the last decade, the traditional view on myeloma treatment has changed dramatically. It is increasingly evident that treatment strategies solely based on targeting intrinsic properties of myeloma cells are insufficient. Lately, approaches that redirect the cells of the otherwise suppressed immune system to take control over myeloma have emerged. Evidence of utility of this principle was initially established by the observation of the graft-versus-myeloma effect in allogeneic stem cell-transplanted patients. A variety of new strategies to harness both innate and antigen-specific immunity against MM have recently been developed and intensively tested in clinical trials. This review aims to give readers a basic understanding of how the immune system can be engaged to treat MM, to summarize the main immunotherapeutic modalities, their current role in clinical care, and future prospects. 
Keywords: multiple myeloma; immunotherapy; immune modulation; allogeneic stem cell transplantation; cancer vaccination; adoptive cell transfer; monoclonal antibodies; immunomodulatory drugs; immunogenic cell death

\section{Introduction}

Multiple myeloma (MM) is a very heterogeneous plasma cell cancer that differs extensively in clinical behavior, prognosis, and response to treatment [1]. MM is almost always preceded by a premalignant stage called monoclonal gammopathy of undetermined significance (MGUS) [2]. Genetic data from MGUS patients have provided evidence that clonal plasma cells already have a genetically advanced landscape at this stage, wherein various clones coexist and carry the same genetic changes as found in malignant MM cells [3-5]. In spite of this genomic complexity, most of MGUS cases are clinically stable, and never progress into MM [6]. Interestingly, animal studies have shown that MGUS cells mediate progressive growth upon xenotransplantation in humanized mice and several other studies have demonstrated the capacity of innate and adaptive immune cells to recognize MM/MGUS cells and potentially mediate the control of tumor growth $[7,8]$. This suggests that the growth rate and clonal evolution of MGUS cells into MM may depend in part on extrinsic factors as for instance immunosurveillance [3,9]. Importantly, the immune system in MM patients demonstrates progressive impairment compared to MGUS stages [10-12]. Several mechanisms have been proposed to be involved in the fading tumor surveillance that may be involved in disease progression, including production of immune-suppressive cytokines, suppression mediated by regulatory T-cells [13-16], myeloid-derived suppressor cells [17], tumor-associated macrophages [18,19], and the expression of inhibitory immune checkpoints on cells present in the tumor microenvironment (TME) [20-22]. Another common feature of disease progression appears to be a suppression of T-cell activity by an increase in ectoenzymatic activity in hypoxic TME. A recent study demonstrated that immunosuppressive adenosine generated in the bone marrow niche through a CD38mediated pathway correlates with the progression of MM $[23,24]$. In addition to adaptive T-cell mechanisms, innate immunity also plays a role in immune-mediated control of MM. In particular, the importance of NK cells in MM control has been demonstrated in several studies [25-27]. Accordingly, NK cells from MM patients show both quantitative and qualitative changes compared to NK cells from healthy donors $[28,29]$. Taken together, this evidence paints a complex picture where progressive immunosuppression associates with MM development. Interactions between tumor plasma cells and the bone marrow (BM) microenvironment contribute to generating an immunosuppressive milieu characterized by a high concentration of immunosuppressive factors, loss of effective antigen presentation, effector cell dysfunction, and expansion of immunosuppressive cell populations [30]. Strategies aimed at increasing immune surveillance and mitigating immunosuppression may have important therapeutic implications in MM, especially for long-term control and potential cure. This article provides an overview of methods (Figure 1) that can be used to harness the immune system in the fight against $\mathrm{MM}$ and put them into the context of current treatment algorithms. 


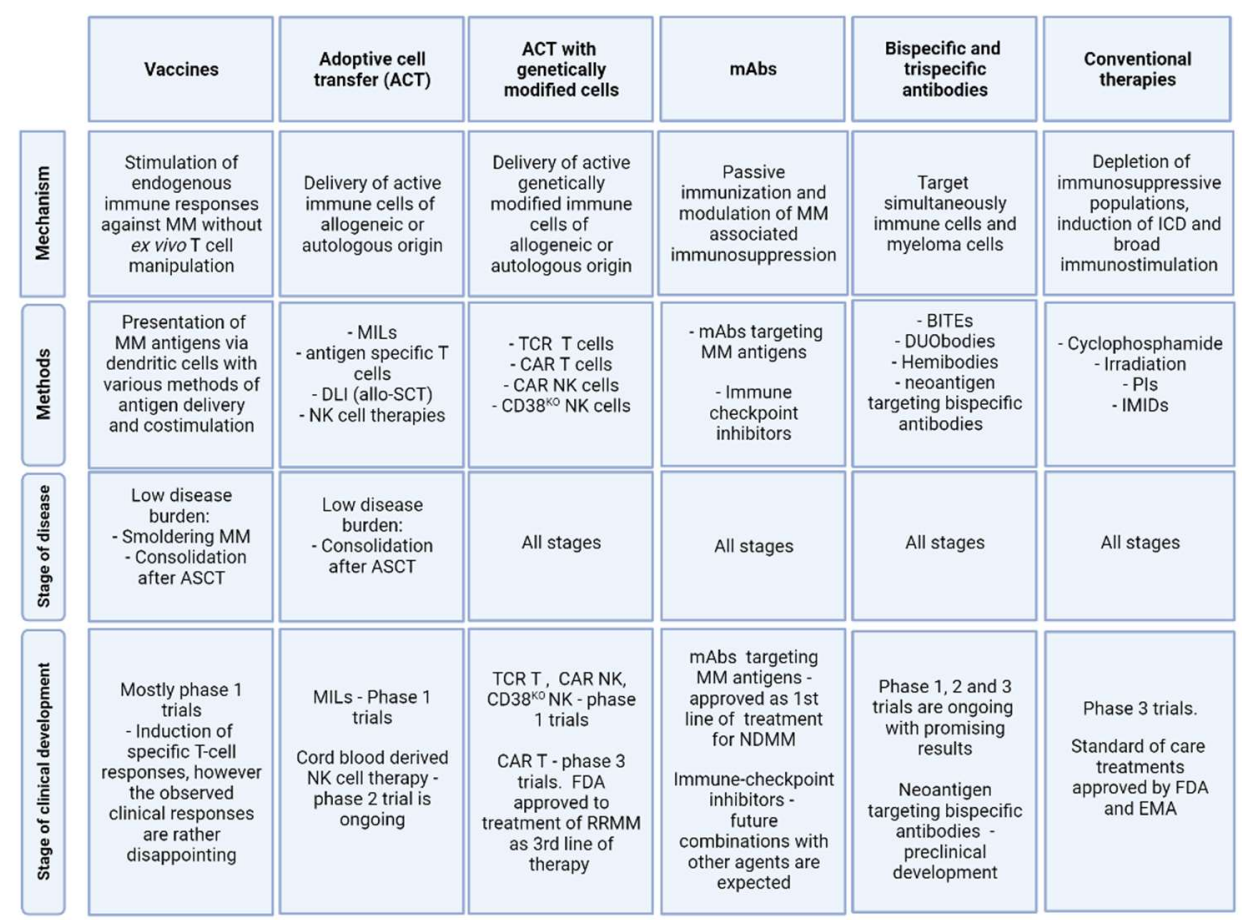

Figure 1. Overview of immunotherapeutic principles in Multiple Myeloma. ASCT: Autologous stem cell transplantation; DLI: Donor lymphocyte infusion; ICD: Immunologic cell death; IMIDs: Immunomodulatory drugs; mAbs: Monoclonal antibodies; MILs: Marrow infiltrating lymphocytes; PIs: Proteasome inhibitors.

\section{T Cell and NK Cell-Dependent Therapies without Genetic Manipulation (Allogeneic Stem Cell Transplantation, Vaccination Strategies)}

\subsection{Allogeneic Stem Cell Transplantation (Allo-SCT)}

Allo-SCT provided the first evidence that MM can be cured by harnessing the immune system [31,32]. Its therapeutic effect, the graft-versus-myeloma (GvM) effect, is based mainly on an alloimmune response of donor T-cells directed against tumor cells. Donor T-cells attacking the tumor cells (Figure 2) are most frequently directed at host (allo)-specific antigens rather than tumor-specific antigens [32]. Therefore, GvM is often accompanied by graft-versus-host disease (GvHD) which needs to be prevented and treated by immunosuppression. GvHD and opportunistic, life-threatening infections cause high non-relapse mortality in allo-transplanted patients. However, it should be recognized that allo-SCT offers a potential cure in a carefully selected subgroup of high-risk MM patients with acceptable toxicity and preserved quality of life [31]. Interestingly, even in HLA-matched transplant settings, the T-cell alloreactivity leading to both GvM and GvHD exists. In these cases, alloreactivity might be caused by T-cell recognition of minor histocompatibility antigens (mHags), polymorphic HLA-bound peptides encoded by genes that differ between donor and recipient $[33,34]$. Variations in intracellular proteins that exist between the donor and recipient are due to the evolutionary occurrence of single nucleotide polymorphisms (SNPs) in the coding regions of the genome, creating peptides that differ in their amino acid sequence [34]. There have been identified mHags expressed in a hematopoietic-specific manner only, which represent a promising target for immunotherapy of hematological malignancies [35]. Various immunotherapeutic strategies using tumor-specific mHag-directed T-cell responses are under clinical development. These include mainly adoptive T-cell transfer with ex vivo generated $\mathrm{mHag}$-specific T-cells and $\mathrm{mHag}$-loaded dendritic cell (DC) vaccination [36-38]. The major limitation for the application of mHag-specific therapy is that donor and recipient need to express the appropriate HLA molecule for presentation of the specific mHag epitope and thus only a small group of patients can be treated with each mHag. With the advances of genomics, novel strategies for the identification of mHags 
have recently been introduced, which might broaden the applicability of this method in the near future [35].

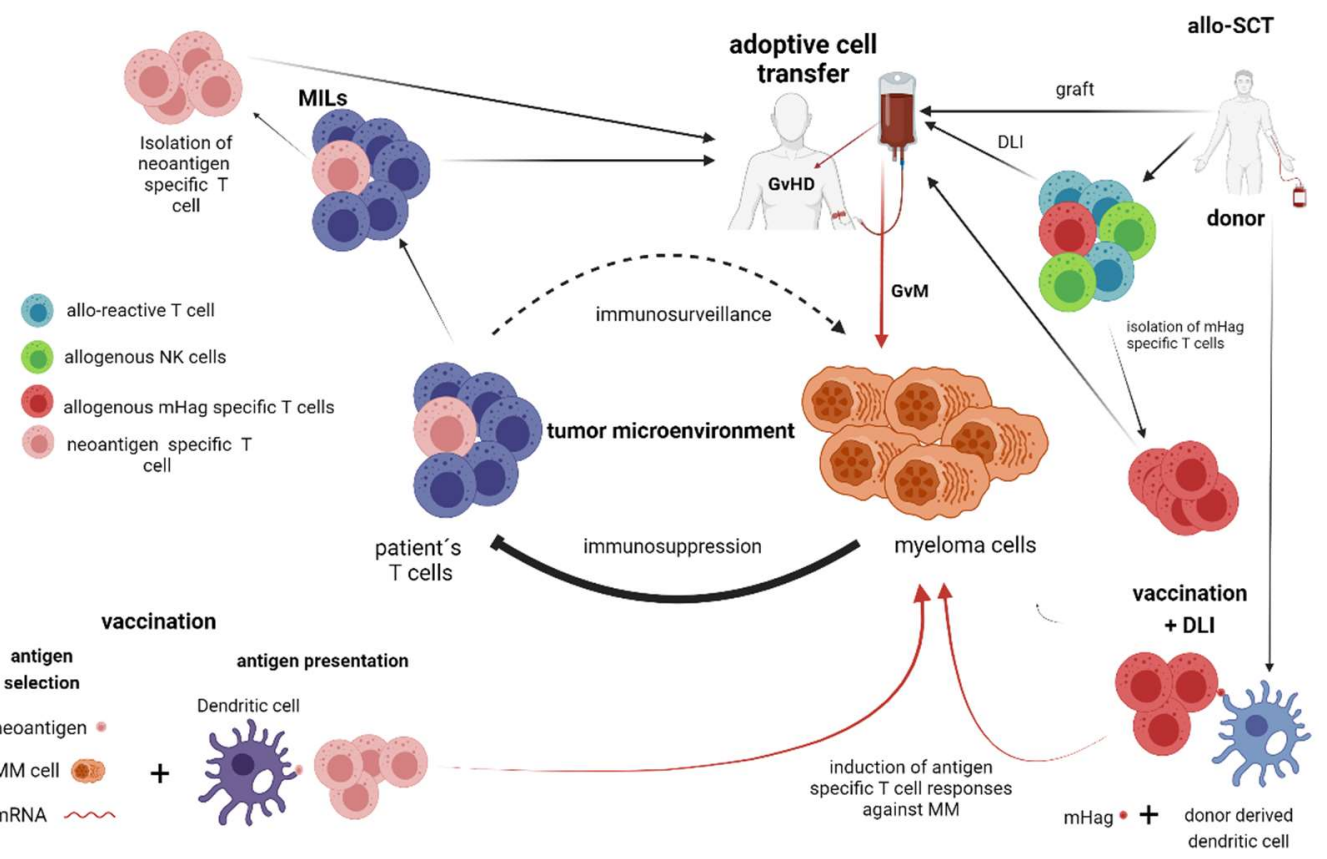

Figure 2. T-cell and NK-cell-dependent therapies without genetic manipulation (allogeneic stem cell transplantation, vaccination strategies, adoptive immune transfer of lymphocytes without genetic manipulation). Allo-SCT: Allogeneic stem cell transplantation; GvM: Graft versus myeloma; IMIDs: immunomodulatory drugs; MILs: Marrow-infiltrating lymphocytes; MDSCs: Myeloid-derived suppressor cells; TAMs: Tumor-associated macrophages; Tregs: Regulatory T cells; mHag: Minor histocompatibility antigen.

\subsection{Vaccination Strategies}

MM vaccination strategies aim to stimulate endogenous immune responses against MM without ex vivo T-cell manipulation (Figure 2). Vaccines have the greatest potential in the prevention of disease progression and, therefore, most vaccine strategies have been tested post autologous stem cell transplantation (post-ASCT) or in smoldering myeloma, where tumor burden is low [39]. Key aspects of the vaccination approach are antigen selection, method of immune presentation, mechanisms to enhance immune responses, e.g., by co-medication, and finally to choose the stage of disease for treatment. Many vaccination strategies use dendritic cell presentation of tumor antigens. Autologous cancer cells themselves can serve as an antigen source, which have the potential to stimulate multiplex immunity to known cancer antigens, patient-specific neoantigens, but also previously unidentified antigens. In this approach, autologous cancer cells are physically fused with the dendritic cells [40]. Such a fusion vaccine was employed in a phase 2 clinical trial where the vaccine was administered post-ASCT. Remarkably, $24 \%$ of patients who achieved a partial response following transplant were converted to CR/nCR after vaccination [40]. Other routinely used dendritic-cell-based approaches are electroporation of dendritic cells with messenger RNAs encoding the myeloma antigens [41] or differentiation of dendritic cells ex vivo in the presence of tumor antigens (peptide loading) [42]. Granulocytemacrophage colony-stimulating factor (GM-CSF) has been extensively investigated as a vaccine adjuvant, based on its ability to recruit and activate dendritic cells in vivo $[39,43]$. GVAX is a vaccine platform in which cells from two myeloma cell lines are admixed with K562 cells modified to express GM-CSF. Durable PFS and emergence of myeloma-specific immune responses were reported in stable patients with low levels of detectable MM on lenalidomide-containing regimens who received GVAX vaccination [44]. GVAX vaccine is currently evaluated in a phase II trial for MM with a $\mathrm{CR} / \mathrm{nCR}$ after initial therapy. The goal 
of this trial is to extend remissions and potentially deepen responses to a minimal residual disease (MRD) negative state (NCT03376477).

The selection of an appropriate antigen is critical for the development of a vaccine strategy that preserves tumor specificity and immunologic efficacy. Cancer/testis (CT) antigens (e.g., NY-ESO-1 and SP17), a group of tumor antigens with normal expression restricted to male germ cells and pathological expression in malignant plasma cells, are frequently used and tested in diverse clinical trials with different designs of vaccines [45]. Interestingly, hypomethylating agents routinely used in hematological praxis have the capacity to increase the expression of $\mathrm{CT}$ antigens and their combination with vaccination against these antigens might be beneficial [46]. Vaccines against normal peptides preferentially expressed by MM cells represent another approach. The vaccine PVX-410, targeting $\mathrm{XBP1}$, CD138, and CS1, has been developed and tested in smoldering myeloma with or without the addition of lenalidomide. Immune responses were observed, as indicated by an increase in the percentage of tetramer-positive cells and interferon $\gamma$-positive cells, which was further enhanced in combination with lenalidomide [47].

With the advances of genomics, tumor-specific mutations (neoantigens) are becoming specific targets for cancer immunotherapy [48-50]. Importantly, a recent study has demonstrated immunogenic neoantigens in $\mathrm{MM}$, which were able to elicit T-cell-specific responses against malignant plasma cells. In addition, shared neoantigens, predicted in oncogenic driver genes, have been identified and it has been proposed that they could be targeted by "off-the-shelf" immunotherapeutic approaches including vaccination [51]. Currently, only one study vaccinating against patient-specific neoantigens (NCT03631043) is ongoing in smoldering MM. In an allo-SCT setting, donor-derived dendritic cells loaded with mHags followed by DLI are capable of inducing objective mHag-specific T-cell responses. However, the observed clinical responses are disappointing, indicating the need for improvements of the current vaccination strategy [37].

There are many challenges in vaccine approaches, including the dysfunctional immune system of MM patients and the inability to generate large numbers of antitumor cells with high affinity for tumor antigens, as well as an immunosuppressive TME that can suppress T-cell effector mechanisms [52]. Current research focuses on further improvements of the vaccination strategy, toward translating the observed T-cell responses induced by vaccination into more robust clinical responses. Many of the difficulties of optimizing vaccination strategies might be overcome by the use of adoptive cell transfer of antitumor immune cells which is further discussed below.

\section{Adaptive Immune Transfer of Autologous and Allogeneic Lymphocytes without Genetic Manipulation-(Marrow-Infiltrating Lymphocytes, Donor Lymphocyte Infusions, Adoptive Transfer of NK-Cells)}

\subsection{Marrow-Infiltrating Lymphocytes (MILs)}

The ability of expanded tumor-infiltrating lymphocytes (TIL) to induce durable clinical remissions in melanoma patients was one of the first demonstrations of the therapeutic potential of lymphocytes isolated from tumor sites [53]. Myeloma-specific T-cells isolated from the $\mathrm{BM}$ of patients with progressive myeloma can generate strong, tumor-specific cytolytic responses to autologous, tumor-loaded dendritic cells [54]. In another study, MILs were also able to target both the terminally differentiated CD138+ plasma cells and the myeloma precursors as was shown by a profound inhibition in a tumor clonogenic assay [55]. The antigens that mediated the recognition of clonal cells in these studies have not been identified. Several recent studies have revealed the critical role of neoantigen-specific T-cells in maintaining durable responses following adoptive cell transfer in epithelial cancer [56-58]. Importantly, MM, compared to epithelial cancers and melanoma, is a malignancy with a lower mutational burden and thereby a lower likelihood of neoantigen-specific T-cells being present in the TME $[59,60]$. However, a recent study has demonstrated that neoantigens in MM are immunogenic and can elicit neoantigen-specific T-cell responses against malignant plasma cells [51]. The whole bulk of isolated and ex vivo expanded MILs from patients (Figure 2) can be safely re-infused as cellular therapy. Such an approach was evaluated 
in a phase 1 clinical trial where MILs were expanded ex vivo and subsequently infused after ASCT as a part of consolidation. This approach induced durable myeloma-specific immune responses that correlated with superior clinical outcomes [61].

More broadly in cancer, the intrinsic capacity of intratumoral T-cells to recognize adjacent tumor tissue seems to be variable [62]. Strategies expanding specifically neoantigenspecific T-cells (Figure 2) have been described and therapeutically used in malignancies other than MM $[49,58,59]$. There is increasing research attention towards identifying and selecting neoantigen-specific T-cells for therapeutic purposes. However, such a "precise targeting" strategy poses a great challenge in terms of the identification and isolation of these cells. To this end, various methods have been proposed and developed [63].

\subsection{Donor Lymphocyte Infusions (DLI)}

DLI is the adoptive transfer of donor lymphocytes to the allogeneic setting and represents an important treatment strategy for patients with hematologic malignancies who have experienced relapse after allogeneic stem-cell transplantation (Allo-SCT) [64]. Nevertheless, the role of donor lymphocyte infusion (DLI) in the treatment of MM is not clearly defined. Lokhorst et al. demonstrated that approximately $50 \%$ of patients might respond to DLI with some patients achieving long-lasting remissions and potentially cure. However, a severe GvHD occurs in the majority of patients and the overall prognosis for allo-transplanted patients with relapsed MM treated with DLI remains rather poor [64]. However, it has been shown that the graft-versus-myeloma (GvM) effect in some cases occurs without GVHD, which might indicate that responses against tumor-specific antigens, as for instance mHags, are involved [64]. More recently, it was suggested that the clinical benefit of DLI might be higher in patients who receive DLI preemptively for treatment of residual disease compared to patients treated at the time of relapse [65]. Interestingly, both $\mathrm{T}$ and NK cells are considered major players in the GvM effect, whereas only T-cells are associated with alloreactivity against healthy tissues and GvHD [66]. Thus, allogeneic NK-cells therapy represents an interesting approach that will be further discussed in the following section.

\subsection{Adoptive Transfer of NK Cells}

An alternative to adoptive T-cell therapies is the transfer of NK cells (Figure 2), which has a direct capacity of killing malignant cells in an antigen-independent manner [67]. There is evidence of NK-cell dysfunction in MM [68-70] which makes NK-cell treatment attractive because NK-cell therapy can, in contrast to T-cell-based therapies, be based on an allogeneic source. Moreover, the use of a haploidentical allogeneic source might be therapeutically beneficial by inducing alloreactivity specifically against malignant cells without significant risk of GvHD [71,72]. NK-cell activity is regulated by a complex interplay of activating and inhibitory signals originating from target cells. Inhibition is provided by killer immunoglobulin-like receptors (KIRs) that recognize allotypic determinants displayed by different human leukocyte antigen (HLA) class I alleles. Inhibitory signals are generally dominant and prevent NK cells from killing autologous cells. Importantly, the number of HLA class I KIR ligands varies among individuals [73]. Therefore, transplantation across histocompatibility barriers may trigger donor NK-cell alloreactivity if the recipient lacks KIR ligands present in the donor. It was demonstrated that NK cells from KIR-ligand mismatched donors exert a potent anti-leukemic effect and prevent relapse after haploidentical transplantation for acute myeloid leukemia (AML) [72]. The potential curative effect of KIR ligand mismatched NK-cell therapies in AML has also been reported by others [74]. In MM, it has been suggested that the GvM effect in an allo-SCT setting is partially mediated by NK cells [75]. However, only a few studies in MM have used allogeneic KIR ligand-mismatched NK cells from haploidentical family donors. This approach has led to in vivo expansion of donor NK cells, but unconvincing response rates [71]. More recently, umbilical cord blood-derived NK cells have also been used in combination with autologous HSCT in 
heavily pretreated and high cytogenetic risk $\mathrm{MM}$ and the results from a phase 1 study encouraged a currently ongoing phase 2 study $[76,77]$.

The use of allogeneic NK cells as immunotherapy for MM remains a promising concept. Importantly, the efficacy of existing MM therapies, including the IMIDs and monoclonal antibodies, relies substantially on endogenous NK cells [78-80]. Because endogenous NK cells are known to be functionally deficient in MM and may even interplay negatively with CD38 targeting therapies [81], there is a rationale for approaches where allogeneic NK cells are used in combination with already approved therapies (Figure 2). Recently, CD38 knockout (CD38 $\left.{ }^{\mathrm{KO}}\right) \mathrm{NK}$ cells from healthy donors were generated. When compared to paired CD38 wild-type NK cells, $\mathrm{CD} 38^{\mathrm{KO}} \mathrm{NK}$ cells showed less fratricide and superior persistence in mice in the presence of the CD38 antibody daratumumab (DARA). Additionally, $\mathrm{CD} 38^{\mathrm{KO}} \mathrm{NK}$ cells exhibited enhanced ADCC against an MM cell line and primary MM cells from a patient with disease relapse on DARA [82]. Thus, using CD $38^{\mathrm{KO}}$ cells has the potential to maximize the clinical efficacy of DARA against MM and this concept is currently being evaluated in a phase 1 clinical trial (NCT04614636).

In the era of adoptive immune cell therapy when genetically modified cells are often used, the fact that therapeutic NK cells might originate from an allogeneic source, without inducing GvHD in the recipient, is currently its biggest advantage over T-cellbased approaches. However, many other differences between NK- and T-cell therapies exist, which originate from their role in the immune system, and both T-cell and NK-cellbased therapies might find their specific applications in different clinical scenarios in the near future. Adoptive transfer of genetically modified immune cells is discussed in the following section.

\section{Adaptive Immune Transfer of Autologous and Allogeneic Lymphocytes with Genetic Manipulation (TCR-Engineered T cells, Chimeric Antigen Receptor T-Cells and Chimeric Antigen Receptor NK-Cells)}

The unique targeting specificity of immune cells can be re-directed by the integration of genes encoding either conventional alpha-beta T-cell receptors (TCR) or chimeric antigen receptors (CAR) (Figure 3). CARs are constructed by linking the antigen recognizing part of an antibody ( $\mathrm{scFv}$ ) to activating intracellular signaling molecules, often including costimulatory domains encoding CD3z, CD28, or CD137 to fully activate T-cells [83]. Many different CAR designs and approaches have been developed and are reviewed elsewhere [84]. Several methods to introduce CAR genes into immune cells with high efficiency exist, however, methods depending on viral vectors are clinically most developed and routinely used in FDA/EMA-approved products [85]. The importance of choosing a safe method for gene transfer is highlighted by a recent reporting of development of CAR T-cell-derived lymphoma in two of ten patients effectively treated with piggyBac modified CD19-specific CAR T-cells [86].

Perhaps the most important consideration confronting the use of genetically engineered cells is the selection of appropriate antigenic specificity of the introduced TCRs or CARs. The potency of T-cells enables the recognition of low levels of antigen expression on normal cells, which has led to severe on-target, off-tumor toxicity in patients [83]. Therefore, suitable antigen targets are those presented exclusively on the cancer or, alternatively, on normal cells that are not essential for survival [83]. Early demonstration of the power of T-cell therapy was demonstrated in melanoma patients who received high-avidity TCRs that recognized melanoma-melanocyte antigens. Although objective cancer regressions were observed, severe off-tumor/on-target toxicity was seen in the skin, eyes, and ears of patients due to the presence of melanocytes in these organs [87]. The same pitfalls of life-threatening on-target, off-tumor toxicities also apply to the use of CARs. A recent, and MM-relevant, demonstration of risk posed by targeting antigens broadly expressed in non-tumor tissues might be represented by CAR T-cells against CD38. While CD38 is broadly expressed in vital tissues, such as the liver and lung smooth muscle cells [88], the target is still considered a safe target for therapy with monoclonal antibodies [80]. However, 
a recent report on treatment with high-affinity CD38-specific CAR T-cells describes lethal adverse events observed after a patient received the anti-CD38 CAR T-cell infusion [89].

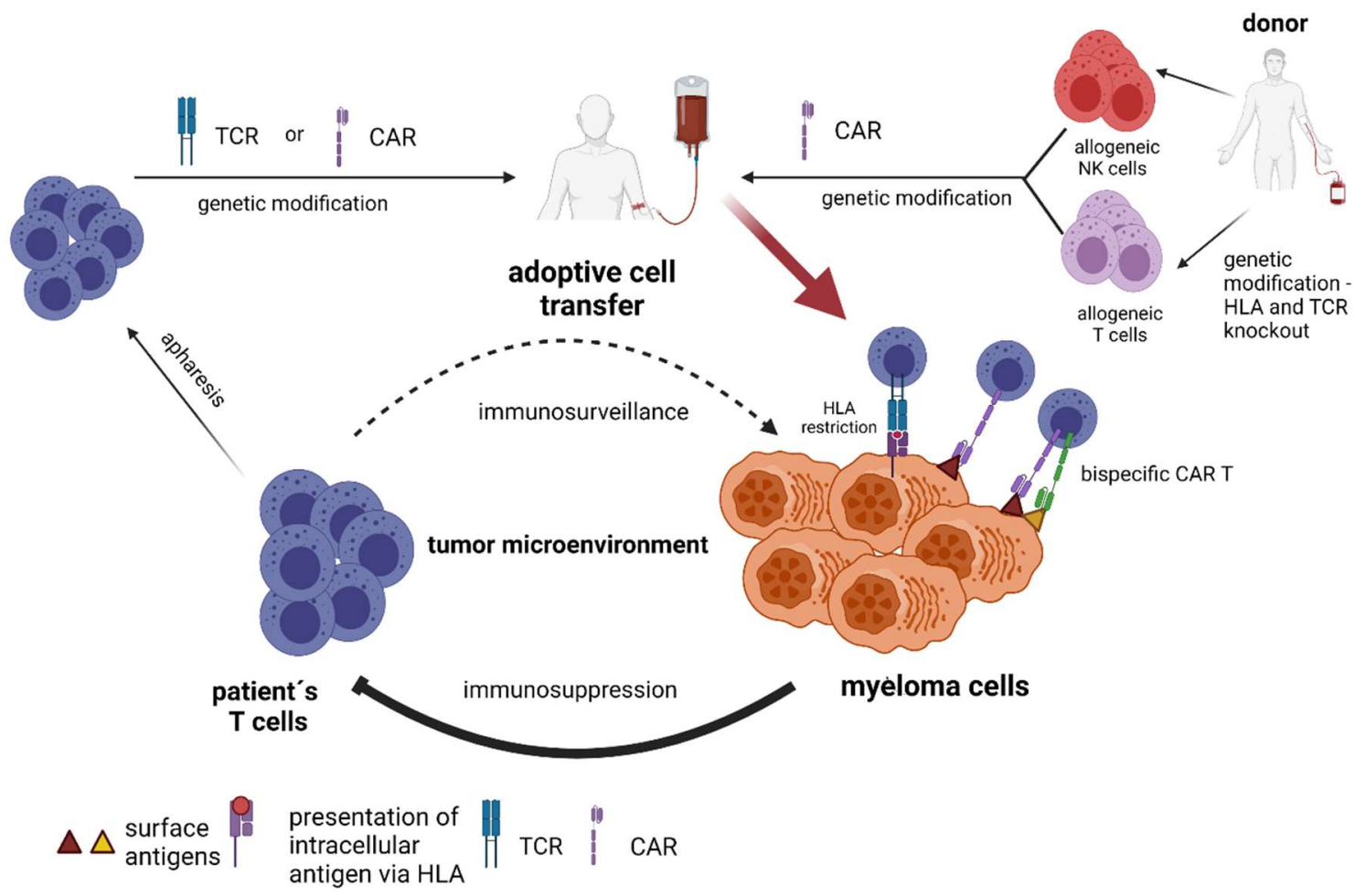

Figure 3. Adoptive immune transfer of autologous and allogeneic lymphocytes with genetic manipulation (TCR-engineered $\mathrm{T}$ cells, chimeric antigen receptor T-cells, and chimeric antigen receptor NK-cells).

\subsection{TCR-Engineered T Cells}

The TCR recognizes peptides that are bound to HLA molecules on the cell surface. The peptides may be derived from both intracellularly and extracellularly expressed protein antigens. The first phase 1 trial of TCR-engineered T-cells in MM targeted the intracellular NY-ESO-1 antigen in HLA A*02:01-positive patients after auto-SCT. In this trial, TCR-engineered T-cells were trafficked to the marrow and showed extended persistence that correlated with encouraging clinical activity against antigen-positive myeloma [90]. Recently, the first two MM patients were treated with CRISPR-modified NY-ESO-1 specific TCR-engineered T-cells. In this study, genes for the PD-1 end endogenous TCR receptor were knocked out to improve T-cell function and persistence [91]. This pilot study demonstrated the safety and feasibility of multiplex CRISPR-Cas9 T-cell human genome engineering in patients with advanced $\mathrm{MM}$, however, the conclusion in regards to efficacy is immature. Importantly, TCR-engineered T-cells can only be used in HLA-compatible patients whose malignant cells also express the targeted protein, thus their applicability is limited.

\subsection{CAR-Engineered T-Cells}

Compared to TCR-engineered T-cells, the introduction of CARs to T-cells provides non-HLA-restricted recognition of cell surface antigens, which significantly increases the spectrum of patients who may be treated. Unfortunately, a limited number of known cell surface antigens are uniformly expressed on plasma cells and not in other vital tissues, and this represents one of the greatest challenges in the development of MM-specific CAR T-cell therapies. Many extracellular proteins that are considered plasma cell-specific in regards to flowcytometric identification are also expressed in peripheral tissues (e.g., CD38, CD56, CD138) $[89,92,93]$. Targeting them thus represents a significant risk for on-target off-tumor toxicities. Interestingly, strategies tuning the antigen affinity of CAR T-cells have 
been described to discriminate healthy and tumor tissues based on their level of antigen expression. Drent et al. demonstrated that CD38-specific CAR T-cells with a reduced affinity could effectively lyse MM cells with a high CD38 expression but spare CD38 low healthy hematopoietic cells in vitro and in vivo [94]. This approach was suggested to be suitable for the generation of optimal CD38-specific CAR T-cells, which would spare healthy tissues and thus extend a spectrum of potentially targetable antigens. However, antigen downregulation is a common escape mechanism in tumors and might represent a major limitation of this approach [92].

\subsection{Anti-BCMA CAR T-Cell Therapy}

Currently, the most prominent example of an antigen targeted by CAR T-cells in MM is the B-cell maturation antigen (BCMA). BCMA is consistently expressed on the surface of normal and malignant plasma cells, thus by mature B cells. BCMA has a crucial role in the survival of long-lived plasma cells in the bone marrow and is not expressed in other vital tissues [93]. There are several BCMA CAR T-cell products in clinical development whose differences and clinical activity are reviewed elsewhere [95,96]. So far, only one of them, idecabtagene vicleucel, has received FDA approval based on recently published results from a phase 2 study (NCT03361748) [97,98], and ciltacabtagene autoleucel has earned FDA priority review [99], both for the indication of relapsed/refractory MM. Several clinical trials of anti-BCMA CAR T-cells have shown high-quality responses, including minimal residual disease negativity in patients with heavily pretreated multiple myeloma. Phase 3 trials are currently evaluating anti-BCMA CAR T-cell therapy versus standard-of-care regimens in patients in earlier stages of the disease and even in newly diagnosed patients with high-risk cytogenetic profiles or with residual disease after transplantation [95].

\subsection{Resistance to Anti-BCMA CAR T-Cell Therapy}

Although most MM patients initially respond to CAR T-cell treatment, only a subset of them have sustained responses for more than 1 year, and almost all patients eventually relapse. Relapses following CAR T-cell treatment are often related to the gradual loss of CAR T-cells, loss of antigen expression on the tumor cell surface known as antigen escape $[95,100,101]$, or to an impaired T-cell activity induced by the immunosuppressive tumor microenvironment [102]. Several strategies to improve the effectiveness of CAR T-cell therapy are under investigation. These include optimizing CAR design and adapting the manufacturing process to generate cell products enriched for subsets of less differentiated T-cells [103]. The potential risk of relapse due to antigen escape and intratumoral heterogeneity with BCMA-negative subclones underscore the importance of targeting additional multiple myeloma-associated cell surface antigens. Several CAR T-cell products specific for other antigens, such as CD19, CD38, CD138, CD229, SLAMF7, and GPRC5D, are currently being evaluated in preclinical or clinical studies, and are reviewed elsewhere $[95,96]$. In addition, dual-antigen targeting combining BCMA with some alternative targets in bispecific CAR constructs proved an ability to prevent antigen escape in a mouse model $[104,105]$. An alternative approach of targeting two antigens simultaneously is represented by ligandbased CAR T-cells, which is based on ligand binding to two different receptors expressed on MM. APRIL-specific CAR T-cells allow for bispecific targeting of the MM-associated antigens BCMA and transmembrane activator and CAML interactor (TACI) which are natural receptors for APRIL ligand and are both uniformly expressed by MM [106]. Several phase 1 studies testing various designs of bispecific CAR T-cells and APRIL-based CAR T-cells are currently ongoing and reviewed elsewhere [98].

\subsection{Allogeneic CAR T-Cells and CAR NK-Cells as 'off the Shelf' Adoptive Therapy}

Using allogeneic CAR T-cells from donors (Figure 3) has many potential advantages over autologous approaches. CAR T-cells manufactured from healthy T-cells which were not exposed to previous lines of therapy and to immunosuppressive tumor microenvironment lead to better CART-cell proliferation and in vivo survival [107], which could, in 
turn, translate into long-lasting responses. In addition, allogeneic T-cells from donors are immediately available and provide a possibility for standardization of the CAR T-cell manufacturing with time for multiple cell modifications, which might decrease costs by using an industrialized process [108]. Conversely, allogeneic CAR T-cells may cause life-threatening GvHD or may be rapidly eliminated by the host immune system [108]. Nevertheless, rapid progress in gene-editing technologies has already resulted in strategies to control the risk of GvHD by efficiently eliminating TCR and HLA expression and have brought new techniques to make allogeneic CAR T-cells invisible to the host immune system [108]. There are currently several phase 1 studies testing anti-BCMA and anti-SLAMF7 allogeneic CAR T-cells in MM (NCT04093596, NCT04244656, NCT04171843, NCT04142619).

An alternative allogeneic source of immune cells that could be equipped with the CAR to kill MM cells is NK cells. Recently, allogeneic KIR mismatched, anti-CD19 CAR NK-cells derived from cord blood have shown to be an effective strategy to treat lymphoma patients [109]; however, there is currently only one running clinical trial investigating CAR NK-cells in MM (NCT03940833) [110]. Most of the ongoing CAR NK-cells trials in malignancies other than MM are testing CAR NK-cell products that are based on original CAR constructs tailored for T-cell activation, which may not be the best way to activate NK-cells. New CAR constructs with different activation domains might thus better reflect NK-cell biology and are in preclinical development. It is conceivable that they will pave the way for the successful development of CAR NK-cell therapy in the near future [111].

Rational combinations of CAR therapies with IMIDs, CD38 antibodies, and checkpoint inhibitors will likely enhance the performance of CAR therapy and will be discussed in the following section.

\section{Strategies Mitigating Immune Resistance-Reviving of Existing Immune Responses and Stimulating Innate Immune System (Standard of Care Treatments, Immune Checkpoints Inhibitors, Bispecific Antibodies)}

\subsection{Standard of Care Treatments}

The potential existence of myeloma-specific T-cell responses in MM patients is limited by the immunosuppressive TME. Strategies, which can mitigate such an immunosuppressive environment, or strategies that can revive and stimulate pre-existing immune responses, exist. Immunomodulatory drugs (IMIDs) are a cornerstone of MM treatment, and as their name suggests, immunomodulation is an important part of their mechanism of action mediated via IMIDs binding to cereblon, which induces enhanced affinity of cereblon to transcription factors IKZF1 and IKZF3. Subsequently, ubiquitination and degradation of these transcription factors lead to changes in gene transcription [112-114], including increased expression of IL-2, which regulates key aspects of T-cell biology. Via pathway signaling, IL-2 triggers critical metabolic and transcriptional changes that lead to T-cell survival, proliferation, and differentiation, which are critical for tumor control (Figure 4) [115].

Even classical chemotherapy might have a beneficial effect on immune-mediated antiMM responses. Depletion of specific immunosuppressive populations has been described with cyclophosphamide treatment. The addition of low-dose cyclophosphamide to the IMID lenalidomide induced responses in lenalidomide refractory patients and a synergistic role of these two agents has been suggested [116]. It is well known that metronomic low-dose cyclophosphamide has multiple effects, including modulation of the microenvironment [117], and improvement of T- and NK-cell-mediated antitumor immune responses via depletion of regulatory T-cells [118-121]. It is unclear whether weekly higher-dose cyclophosphamide has the same effects on the bone marrow microenvironment compared with continuous low-dose cyclophosphamide (Figure 4) [116]. 


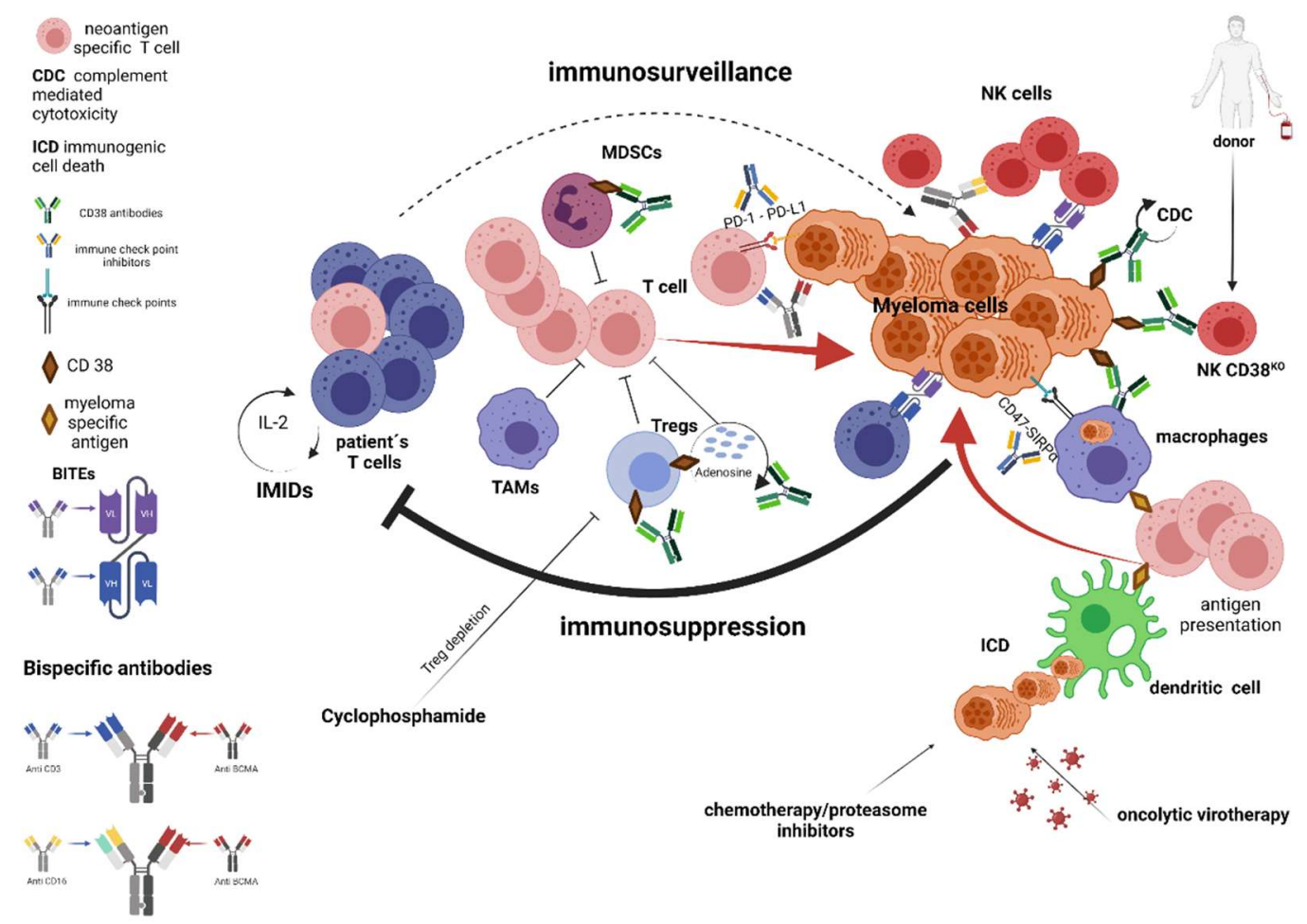

Figure 4. Strategies mitigating immune resistance-reviving of existing immune responses and stimulating innate immune system. ICD: Immunologic cell death; IMIDs: Immunomodulatory drugs; MILs: Marrow infiltrating lymphocytes; MDSCs: Myeloid-derived suppressor cells; TAMs: Tumor-associated macrophages, Tregs: Regulatory T cells.

Certain anti-MM agents are able to provoke potent adaptive immune responses by inducing immunogenic cell death (ICD) [122] (Figure 4). Interestingly, there is a connection between endoplasmic reticulum (ER) stress and the occurrence of ICD [123]. MM cells display enhanced ER stress, hence making them dependent on ER stress-related survival pathways [123]. Compounds that target these survival pathways or that induce excessive amounts of ER stress are very effective in targeting MM cells, and it is tempting to speculate that ICD is an important mode of action of MM treatment as recently demonstrated for bortezomib [124]. Even radiation therapy might have an abscopal effect [125], which is a phenomenon of tumor regression in sites distant from targeted fields of irradiation and might be explained by the systemic immune response that radiation causes [126].

\subsection{Monoclonal Antibodies Targeting CD38}

Treatment with $\mathrm{mAbs}$ has recently become a milestone in the successful treatment of MM, outstandingly exemplified by daratumumab (DARA), a human CD38 mAb [80]. Treatment of MM with DARA is a passive immunization (Figure 4). After infusion, DARA binds to its target CD38 on MM cells, which in turn leads to activation of innate immune mechanisms (NK cells, complement system, and macrophages) to kill MM cells. It was demonstrated that high CD38 expression levels on the MM cell surface are important for effective killing by complement-mediated mechanisms and NK cells [127]. Nevertheless, DARA treatment leads to a reduction in CD38 levels on MM cells within a few hours after the first infusion [128,129]. Moreover, CD38-positive NK cells, the main effector cell population, are depleted by DARA-induced fratricide [81]. Therefore, it has been speculated how the downregulated CD38 expression is consistent with observed sustained responses to DARA treatment [130]. Recent data has suggested that CD38 metabolic pathways involving the production of immune-suppressive factor adenosine play an important role as a potential mechanism behind the suppression of adaptive immune responses [131,132]. It is therefore conceivable that the down-regulation of CD38 on both MM cells and cells of the tumor microenvironment by DARA treatment may lead to an 
improved adaptive immune response against MM cells [129]. In addition, DARA also eliminates CD38-positive immune suppressor cells, including regulatory T-cells, regulatory B cells, and myeloid-derived suppressor cells [133]. Altogether, DARA treatment results in a less immunosuppressive microenvironment, which explains why patients treated with this antibody experience clonal expansion of T-cells in both peripheral blood and bone marrow [133]. Importantly, the same induction of clonal T-cell expansion occurs with another CD38 mAb, isatuximab (ISA) [134] which coincides with an emerging adaptive immune response against myeloma-associated antigens NY-ESO-1 and CD38 [135], induced by ISA treatment. Interestingly, in DARA- and ISA-treated patients, the increase in T-cell clonality positively correlates with the response to treatment, suggesting that unique immunomodulatory characteristics of the CD38 target molecule and its downregulation by DARA mediated trogocytosis may actually be one of the explanations that CD38 antibodies show single-agent activity in MM $[128,129]$. These immunomodulatory properties of CD38 antibodies support the use of CD38 antibodies with other treatment modalities that enhance T-cell-mediated cytotoxicity as later discussed.

\subsection{Immune Checkpoints Inhibitors}

The discovery of immune checkpoint pathways, their role in the evasion from immune surveillance, and the development of blocking antibodies represent one of the greatest achievements in cancer treatment, which was also recently rewarded by the Nobel Prize [136]. The majority of studies in MM have focused on the inhibitory PD-1/PD-L1 pathway (Figure 4), but many more pathways are crucial for the function of the immune system and may be therapeutically manipulated [20]. The pre-clinical finding of high PD-L1 expression in malignant plasma cells, coupled with evidence suggesting a role for PD-L1 in the development of myeloma clonal resistance and relapse, drove the field towards pursuing immune checkpoint inhibitors in myeloma [137-139]. However, initial enthusiasm was followed by unsatisfying clinical results, and the potential role of PD-1/PD-L1 pathway inhibitors in MM is still a matter of debate. Based on preclinical data, IMIDs and DARA seemed to be ideal partners for the combination treatment $[131,138,140,141]$ and early phase studies of the PD-1 inhibitor pembrolizumab, in combination with standard-of-care regimens for myeloma, showed promising results [142]. Nevertheless, excessive toxicity of the combination of pembrolizumab with lenalidomide or pomalidomide in phase 3 trials caused the FDA to suspend several trials in myeloma patients [143-145]. Combination studies of PD-1/PD-L1 pathway inhibitors with DARA have also been terminated based on results from a phase $\mathrm{Ib} / \mathrm{II}$ LUC2001 study (NCT03023423). This study evaluated the efficacy and safety of a PD-L1 inhibitor, atezolizumab, with or without DARA in patients with advanced or metastatic non-small-cell lung cancer. No extra efficacy, but imbalanced death rates, were observed [141]. As a result, the sponsor stopped further enrollment on all studies with PD-1 or PD-L1 inhibitors combined with DARA [146].

Despite these disappointing results, the PD-1/PD-L1 pathway remains a viable treatment target in MM. Poor T-cell expansion and short-term T-cell persistence represent one of the main causes for the lack of response and relapse in therapies dependent on T-cell function (CAR T-cells, bispecific antibodies) [95]. It has been demonstrated that CAR T-cells from non-responders showed upregulated pathways involved in exhaustion and apoptosis [147]. Accordingly, the expression levels of T-cell co-inhibitory receptors in non-responders, such as PD-1, Tim-3, and LAG-3, were upregulated on CAR T-cells, suggesting possible inhibitory effects induced by these molecules [148,149]. Interestingly, PD-1 blockade resulted in clinical responses in a subset of patients with progression of B-cell lymphoma after anti-CD19-directed CAR T-cell therapy [148,149], and importantly, also in myeloma patients with a progression after anti-BCMA CAR T-cell therapy [150]. These observations demonstrated the proof of principle that inhibition of the PD-1/PD-L1 pathway can induce CAR T-cell re-expansion and responses in patients progressing after CAR T-cell treatment. 
An "armored" CAR T-cell is among several approaches aiming to improve functions of engineered CAR T-cells by preventing T-cell exhaustion, enhancing killing function, and T-cell persistence [151]. Engineering CAR T-cells to secrete PD-1 or PD-L1 antibodies could prevent endogenous PD-1/PD-L1 axis activation in the TME, and thereby alleviate immune evasion $[152,153]$. An ongoing phase 1 clinical trial is exploring the safety of BCMA CAR T-cells secreting a mutant PD-1 Fc fusion protein (NCT04162119). Alternatively, the genome-editing technique may be used to silence PD-1 expression in T-cells and thus prevent T-cell exhaustion/activation cell death [91,154].

There are several clinical trials evaluating agents targeting other immune checkpoint pathways than the PD-L1/PD-1 pathway. LAG-3 and TIGIT antibodies are currently being evaluated as a monotherapy or in combination with standard treatments in MM (NCT04150965 and NCT04354246). Another promising immunotherapeutic target in MM is the macrophage immune checkpoint CD47 that provides a "do not eat me" anti-phagocytic signal. This molecule is overexpressed by virtually all cancers to enable the immune evasion of macrophages and other phagocytes [155]. CD47 overexpression is an independent predictor of a poor prognosis in patients with various cancer types, including hematological malignancies [21]. Anti-CD47 antibodies can induce phagocytosis of tumor cells by the blockade of CD47 and its ligand SIRP $\alpha[155,156]$. In addition, CD47 antibodies induce an antitumor T-cell response by the cross-presentation of tumor antigens by phagocytes to T-cells (Figure 4) [157]. Thus, administration of CD47 antibodies together with an MMtargeting antibody such as DARA or elotuzumab might promote MM elimination in the same way as demonstrated in lymphoma patients treated simultaneously with rituximab and CD47 antibodies $[155,158]$. There are currently two clinical trials evaluating CD47 antibody (NCT04445701) and SIRP $\alpha$-IgG4 Fc ligand (NCT03530683) as a monotherapy or in combination with bortezomib and dexamethasone in RRMM. Simultaneous targeting two different inhibitory pathways might be beneficial as demonstrated in the case of malignant melanoma [159].

\subsection{Bispecific Monoclonal Antibodies}

Bispecific monoclonal antibody (bsMAb) concomitantly binds to two different antigens, commonly the one being on T-cells and the other being an MM-associated antigen, thereby redirecting T-cells toward the MM cells (Figure 4). Thus, bsMAbs rely on the patient's T-cells to elicit an antitumor response. The bsMAbs have the obvious advantage of being a true "off-the-shelf" product without the need for ex vivo genetic manipulation as seen with CAR T-cells [160]. Various bispecific antibody platforms are currently in clinical trials and technologies to build bsMAbs are reviewed elsewhere [161]. The majority of clinical trial data for bsMAbs in MM relates to the BiTE ${ }^{\circledR}$ and DuoBody ${ }^{\circledR}$ platforms. While a BiTE molecule consists of two different single-chain variable fragments (scFv), a DuoBody is a mAb with two different antigen-binding fragments $(\mathrm{Fab})$ and a functional constant region fragment $(\mathrm{Fc})$. The presence of the $\mathrm{Fc}$ domain can promote the stability of the molecule and increase the half-life time of DuoBodies [161]. BsMAbs in clinical development target the same spectrum of antigens as CAR T-cells treatment, with BCMAtargeting bsMAbs as the most advanced in terms of clinical testing. Nevertheless, clinical development of products targeting other antigens such as GPRC5D, CD38, or FcRH5 is ongoing [160]. Bispecific antibodies targeting other MM-associated antigens may be useful in patients with low baseline BCMA expression or heterogeneous BCMA expression. In addition, as in the case of CAR T-cells, treatment with bispecific antibodies may lead to antigen escape [162]. Thus, treatment with a bispecific antibody targeting another antigen may be more effective. In addition, a combination of bispecific antibodies, simultaneously targeting different antigens, may mitigate tumor antigen escape [163]. BCMA/CD3 BiTE AMG420 is the first-in-class bsMAb in MM. In a phase 1 trial, $70 \%$ of patients treated with the maximum tolerated dose achieved a partial remission or better, with minimal residual disease (MRD) negative CR in 50\% of patients [162]. A major limitation of the early BiTE products, including AMG420, is their short half-life time, which requires continuous infu- 
sion in order to achieve a steady therapeutic plasma level. Several other BCMA/CD3 BiTEs or DuoBodies with an extended half-life time, such as AMG701, CC-93269, teclistamab, and REGN-5458, have since emerged and are under rapid clinical development. Their preliminary clinical characteristics are reviewed here [160]. Notably, most BCMA targeting BsMAbs show a relatively similar safety profile and efficacy in patients treated with the maximum tolerated dose. Dose expansion parts of these studies are currently ongoing, and phase 3 trials are upcoming.

Interestingly, in vitro experiments demonstrated that the direct combination of BCMA/ CD3 DuoBody teclistamab with DARA enhances MM cell lysis in an additive fashion. Teclistamab-mediated tumor cell lysis was superior when T-cells obtained from patients treated with DARA were used, compared to T-cells from DARA naïve MM patients [164]. This positive effect of DARA, on the ability of teclistamab to kill MM cells, might be related to the immune-stimulating effects of DARA already mentioned [133]. These data formed a rationale for the first clinical trial investigating bsMAbs as part of a multi-targeted combination therapy. A phase 1 TRIMM study is evaluating the efficacy of teclistamab plus DARA in RRMM (NCT04108195, https:/ / clinicaltrials.gov/ct2/show /NCT04108195) (accessed on 7 June 2021). IMiDs might also provide T-cell-stimulating effects and thus are a promising partner for bispecific antibodies. Indeed, pretreatment of effector cells with lenalidomide or pomalidomide enhanced AMG701-mediated lysis of MM cells [165]. As already mentioned, checkpoint signaling is an important immunosuppressive component of the myeloma microenvironment [138], which might limit the anti-myeloma activity of the bsMAbs. Importantly, it was shown that PD-L1 blockade may enhance bsMAbs-induced MM cell elimination in vitro [166]. Currently, several clinical studies are investigating the concept of bsMAbs/checkpoint inhibition combination therapies in B-cell malignancies (NCT02879695, https:/ / clinicaltrials.gov/ct2/show / NCT02879695 (accessed on 7 June 2021), NCT03340766, https: / / clinicaltrials.gov/ct2/show/NCT03340766) (accessed on 7 June 2021), and promising first safety data have been reported for combining CD19/CD3 BiTE blinatumumab and PD-1 inhibitor pembrolizumab [167].

The first experience with bsMAbs suggested a lower response of these agents compared to CAR T-cell therapy. Interestingly, in contrast to CAR T-cells, bsMAbs do not provide a co-stimulatory T-cell signal via CD137 or CD28 molecules, which might induce T-cell anergy and thus compromise the efficacy of bsMAbs. In vitro data has shown that CD28 co-stimulation enhances the efficacy of CD19/CD3 bsMAbs, a finding reminiscent of data obtained with CAR T-cells when significant improvements in their potency were achieved after the inclusion of co-stimulatory signaling moieties in the CAR constructs [168]. Therefore, the concept of tri-specific antibody (tsMAb) has emerged. TsMAb targets three antigens: a cancer cell, a receptor that activates T- cells, and a T-cell protein that promotes long-lasting T-cell activity against the cancer cell [169]. SAR442257 represents a new trispecific monoclonal antibody that binds to CD3 and CD28 on T-cells and CD38 expressed on MM cells. The resulting cross-linkage may trigger a potent cytotoxic T-lymphocyte (CTL) response against CD38-expressing tumor cells [169]. In addition, SAR442257 can also directly target CD28 expressed on MM cells, thereby enhancing the anti-tumor activity of this agent and allowing it to bind to tumor cells when CD38 is downregulated after treatment with CD38 antibodies [170]. SAR442257 is currently being investigated in a phase 1 study in RRMM (NCT04401020).

Recently, an interesting concept of on-target restoration of a split T-cell-engaging antibody has emerged. This approach is based on a T-cell-engaging antibody derivative that comes in two complementary halves called hemibodies and addresses antigen combinations instead of single molecules [171]. Two different hemibodies contain an antigen-specific $\mathrm{scFv}$ fused to the variable light or variable heavy chain domains of a CD3 antibody. When the two hemibodies simultaneously bind their respective antigens on a single cell, they align and reconstitute the original CD3-binding site to engage $\mathrm{T}$ cells. In preclinical models, hemibodies could preferentially induce the cellular lysis of double-positive cells and spare single-positive cells [171]. 
More recently, the discovery of scFv that recognizes peptides derived from mutant p53 presented via the HLA class I molecule, provided a promising approach for targeting previously non-druggable intracellular targets presented by tumor cells at very low density [172]. It was demonstrated that bsMAbs comprising an $\mathrm{scFv}$ specific for mutant p53/HLA-A2 fused to an scFv specific for CD3 activated with high sensitivity T-cells in vitro to lyse MM cells expressing less than 10 copies of p53/HLA-A2 complexes per cell. Moreover, immunodeficient mice engrafted with human T-cells suppressed the growth of a human MM cell line expressing an average of 2.4 copies of p53/HLA-A2 per cell after treatment with the p53/CD3 bsMAbs [173]. Unfortunately, the polymorphic nature of classical HLA class I limits the individuals to be targeted with this approach. To broaden population coverage, an alternative may be to find neoantigen peptides presented by non-classical HLA (that is, HLA-E and HLA-G). Unlike classical HLA, HLA-E and HLA-G are essentially monomorphic, and their preponderance is up-regulated on cancer cells. Whether HLA-E and HLA-G present peptides from shared MM neoantigens may be worth investigating [172].

BsMAbs and tsMAbs engaging NK cells are also being explored in preclinical and clinical studies. RO7297089 (AFM26), a BCMA/CD16A-directed bsMAb induced NK cell-mediated lysis of BCMA-positive myeloma cell lines in vitro and is currently being investigated in a phase 1 study (NCT04434469) [174]. Although still in the preclinical stage of development, trispecific NK cell engager showed promising in vitro results. TsMAb targeting CD16A and the MM antigens BCMA and CD200 induced enhanced cytotoxicity of BCMA and CD200 double-positive myeloma cells compared with single-positive cells [175].

\section{Oncolytic Virotherapy}

The oncolytic potential of viruses was first recognized almost four decades ago when a series of case studies documented the regression of various hematological malignancies in patients with concurrent measles infections $[176,177]$ Oncolytic virotherapy yields results from the direct killing of malignant cells by oncolytic virus replication in cancer cells. Interestingly, MM-specific mutations in the RAS pathway [178] and overexpression of some cell-surface proteins that are commonly used as viral entry receptors render MM cells sensitive to viral infection [179-181]. Moreover, the oncolytic death of infected MM cells is immunogenic and promotes cross-presentation of released MM proteins by tumor-resident antigen-presenting cells, and thereby also enhancing antitumor adaptive T-cell responses (Figure 4) [182]. Oncolytic viruses are derived from naturally occurring strains that can be further genetically modified to increase their specificity to MM cells and enhance their ability to promote tumor clearance. Several oncolytic viruses that have been proposed as therapeutics in MM are reviewed elsewhere [180,181]. The most prominent example is a measles virus (MV-NIS) engineered to express the human thyroidal sodium iodide symporter (NIS). The NIS construct allows for the concentration of radioiodine in tumor cells, which can be utilized both for noninvasive in vivo visualization of virus-infected cells using single-photon emission computed tomography or in therapeutic synergy with $\beta$-emitting radioiodine $[183,184]$. It has been demonstrated that MV-NIS could induce significant tumor regression in myeloma xenografts, as well as in MV-resistant MM tumors when combined with $\mathrm{I}^{131}$ radiotherapy [183]. MV-NIS uses CD46 receptors to enter MM and to drive intercellular fusion of infected cells with their uninfected neighbors, resulting in the formation of nonviable multinucleated syncytia [183]. Myeloma plasma cells overexpress CD46 and are therefore highly susceptible to MV-NIS killing [179]. In a completed phase 1 dose-escalation study, only 1 out of 27 treated patients achieved complete remission, however, less durable decreases in myeloma-specific IgG and/or serum-free light chain (FLCs) levels were seen in other patients [185]. Only two additional patients were enrolled in a dose-expansion phase 2 study evaluating MV-NIS with cyclophosphamide in MM. Both patients passed away while enrolled, and the study has been terminated. Recently reported results of a phase 1 trial, NCT03017820, showed that systemic administration of genetically modified vesicular stomatitis virus (VSV) to patients with heavily pretreated hematological 
malignancies did not induce any objective responses in MM patients, however, responses have been observed in patients with $\mathrm{T}$ cell lymphoma and future trials of combination strategies with immune-modulatory drugs are currently being planned [186].

\section{Conclusions}

Immune dysfunction is a hallmark of MM and worsens by disease progression. Immunotherapy aims to overcome this immune dysfunction by harnessing the host immune system to treat MM, and several immunotherapeutic approaches are being developed and are undergoing current clinical testing (Figure 1). The ultimate goal is to cure MM, however, so far, only a few patients treated with allogeneic immune cells (allo-SCT) have achieved this, suggesting that autologous immune cells from MM patients might be incapable of achieving long-term MM control. Therefore, using an allogeneic source of immune cells for CAR T-cells or CAR NK-cells might represent a promising strategy. In addition, combination therapies of the new T-cell or NK-cell engaging approaches with immunomodulating agents are promising as the next wave of treatment. Neoantigen-specific antibodies/CAR Tcells could further widen the spectrum by targeting oncogenic driver mutations. Data from clinical trials testing all these new approaches and their combinations are eagerly awaited.

Author Contributions: Writing - original draft preparation, J.K. and N.A.; writing-review and editing, M.B.B., C.G.N. and T.S.L., T.B.; supervision, N.A. All authors have read and agreed to the published version of the manuscript.

Funding: This research received no external funding.

Acknowledgments: Figures and table presented here were created with BioRender.com.

Conflicts of Interest: The authors declare no conflict of interest.

\section{References}

1. De Mel, S.; Lim, S.H.; Tung, M.L.; Chng, W.-J. Implications of Heterogeneity in Multiple Myeloma. BioMed Res. Int. 2014, 2014, 232546. [CrossRef] [PubMed]

2. Landgren, O.; Kyle, R.A.; Rajkumar, S.V. From Myeloma Precursor Disease to Multiple Myeloma: New Diagnostic Concepts and Opportunities for Early Intervention. Clin. Cancer Res. 2011, 17, 1243-1252. [CrossRef] [PubMed]

3. Dhodapkar, M.V. MGUS to Myeloma: A Mysterious Gammopathy of Underexplored Significance. Blood 2016, 128, 2599-2606. [CrossRef]

4. Mikulasova, A.; Wardell, C.P.; Murison, A.; Boyle, E.M.; Jackson, G.H.; Smetana, J.; Kufova, Z.; Pour, L.; Sandecka, V.; Almasi, M.; et al. The Spectrum of Somatic Mutations in Monoclonal Gammopathy of Undetermined Significance Indicates a Less Complex Genomic Landscape than That in Multiple Myeloma. Haematologica 2017, 102, 1617-1625. [CrossRef]

5. Morgan, G.J.; Walker, B.A.; Davies, F.E. The Genetic Architecture of Multiple Myeloma. Nat. Rev. Cancer 2012, 12, 335-348. [CrossRef]

6. Kyle, R.A.; Larson, D.R.; Therneau, T.M.; Dispenzieri, A.; Kumar, S.; Cerhan, J.R.; Rajkumar, S.V. Long-Term Follow-up of Monoclonal Gammopathy of Undetermined Significance. N. Engl. J. Med. 2018, 378, 241-249. [CrossRef]

7. Dhodapkar, M.V. Harnessing Host Immune Responses to Preneoplasia: Promise and Challenges. Cancer Immunol. Immunother. 2005, 54, 409-413. [CrossRef]

8. Das, R.; Strowig, T.; Verma, R.; Koduru, S.; Hafemann, A.; Hopf, S.; Kocoglu, M.H.; Borsotti, C.; Zhang, L.; Branagan, A.; et al Microenvironment-Dependent Growth of Preneoplastic and Malignant Plasma Cells in Humanized Mice. Nat. Med. 2016, 22, 1351-1357. [CrossRef] [PubMed]

9. Guillerey, C.; Ferrari de Andrade, L.; Vuckovic, S.; Miles, K.; Ngiow, S.F.; Yong, M.C.R.; Teng, M.W.L.; Colonna, M.; Ritchie, D.S.; Chesi, M.; et al. Immunosurveillance and Therapy of Multiple Myeloma Are CD226 Dependent. J. Clin. Investig. 2015, 125, 2077-2089. [CrossRef]

10. Romano, A.; Conticello, C.; Cavalli, M.; Vetro, C.; La Fauci, A.; Parrinello, N.L.; Di Raimondo, F. Immunological Dysregulation in Multiple Myeloma Microenvironment. BioMed Res. Int. 2014, 2014, 198539. [CrossRef] [PubMed]

11. Díaz-Tejedor, A.; Lorenzo-Mohamed, M.; Puig, N.; García-Sanz, R.; Mateos, M.-V.; Garayoa, M.; Paíno, T. Immune System Alterations in Multiple Myeloma: Molecular Mechanisms and Therapeutic Strategies to Reverse Immunosuppression. Cancers 2021, 13, 1353. [CrossRef] [PubMed]

12. Leblay, N.; Maity, R.; Hasan, F.; Neri, P. Deregulation of Adaptive T Cell Immunity in Multiple Myeloma: Insights Into Mechanisms and Therapeutic Opportunities. Front. Oncol. 2020, 10, 636. [CrossRef] [PubMed] 
13. Prabhala, R.H.; Pelluru, D.; Fulciniti, M.; Prabhala, H.K.; Nanjappa, P.; Song, W.; Pai, C.; Amin, S.; Tai, Y.-T.; Richardson, P.G.; et al. Elevated IL-17 Produced by Th17 Cells Promotes Myeloma Cell Growth and Inhibits Immune Function in Multiple Myeloma. Blood 2010, 115, 5385-5392. [CrossRef]

14. Brown, R.; Murray, A.; Pope, B.; Sze, D.M.; Gibson, J.; Joy Ho, P.; Hart, D.; Joshua, D. Either Interleukin-12 or Interferon- $\gamma$ Can Correct the Dendritic Cell Defect Induced by Transforming Growth Factor B1 in Patients with Myeloma. Br. J. Haematol. 2004, 125, 743-748. [CrossRef] [PubMed]

15. Kawano, Y.; Moschetta, M.; Kokubun, K.; Lukyanchykov, P.; Sula Karreci, E.; Manier, S.; Tsukamoto, S.; Takagi, S.; Shi, J.; Reagan, M.R.; et al. Characterization of the Role of Regulatory T Cells (Tregs) in Inducing Progression of Multiple Myeloma. Blood 2015, 126, 502. [CrossRef]

16. Muthu Raja, K.R.; Rihova, L.; Zahradova, L.; Klincova, M.; Penka, M.; Hajek, R. Increased T Regulatory Cells Are Associated with Adverse Clinical Features and Predict Progression in Multiple Myeloma. PLoS ONE 2012, 7, e47077. [CrossRef]

17. Perez, C.; Botta, C.; Zabaleta, A.; Puig, N.; Cedena, M.-T.; Goicoechea, I.; Alameda, D.; San José-Eneriz, E.; Merino, J.; RodríguezOtero, P.; et al. Immunogenomic Identification and Characterization of Granulocytic Myeloid-Derived Suppressor Cells in Multiple Myeloma. Blood 2020, 136, 199-209. [CrossRef]

18. Andersen, M.N.; Andersen, N.F.; Lauridsen, K.L.; Etzerodt, A.; Sorensen, B.S.; Abildgaard, N.; Plesner, T.; Hokland, M.; Møller, H.J. STAT3 Is Over-Activated within CD163pos Bone Marrow Macrophages in Both Multiple Myeloma and the Benign Pre-Condition MGUS. Cancer Immunol. Immunother. 2021. [CrossRef]

19. Asimakopoulos, F.; Kim, J.; Denu, R.A.; Hope, C.; Jensen, J.L.; Ollar, S.J.; Hebron, E.; Flanagan, C.; Callander, N.; Hematti, P. Macrophages in Multiple Myeloma: Emerging Concepts and Therapeutic Implications. Leuk Lymphoma 2013, 54, $2112-2121$. [CrossRef]

20. Jelinek, T.; Paiva, B.; Hajek, R. Update on PD-1/PD-L1 Inhibitors in Multiple Myeloma. Front. Immunol 2018, 9, 2431. [CrossRef]

21. Sun, J.; Muz, B.; Alhallak, K.; Markovic, M.; Gurley, S.; Wang, Z.; Guenthner, N.; Wasden, K.; Fiala, M.; King, J.; et al. Targeting CD47 as a Novel Immunotherapy for Multiple Myeloma. Cancers (Basel) 2020, 12, 305. [CrossRef]

22. Guillerey, C.; Harjunpää, H.; Carrié, N.; Kassem, S.; Teo, T.; Miles, K.; Krumeich, S.; Weulersse, M.; Cuisinier, M.; Stannard, K.; et al. TIGIT Immune Checkpoint Blockade Restores CD8+ T-Cell Immunity against Multiple Myeloma. Blood 2018, 132, 1689-1694. [CrossRef]

23. Häusler, S.F.M.; Montalbán del Barrio, I.; Strohschein, J.; Anoop Chandran, P.; Engel, J.B.; Hönig, A.; Ossadnik, M.; Horn, E.; Fischer, B.; Krockenberger, M.; et al. Ectonucleotidases CD39 and CD73 on OvCA Cells Are Potent Adenosine-Generating Enzymes Responsible for Adenosine Receptor 2A-Dependent Suppression of T Cell Function and NK Cell Cytotoxicity. Cancer Immunol. Immunother. 2011, 60, 1405. [CrossRef]

24. Horenstein, A.L.; Quarona, V.; Toscani, D.; Costa, F.; Chillemi, A.; Pistoia, V.; Giuliani, N.; Malavasi, F. Adenosine Generated in the Bone Marrow Niche Through a CD38-Mediated Pathway Correlates With Progression of Human Myeloma. Mol. Med. 2016, 22, 694-704. [CrossRef] [PubMed]

25. Ponzetta, A.; Benigni, G.; Antonangeli, F.; Sciumè, G.; Sanseviero, E.; Zingoni, A.; Ricciardi, M.R.; Petrucci, M.T.; Santoni, A.; Bernardini, G. Multiple Myeloma Impairs Bone Marrow Localization of Effector Natural Killer Cells by Altering the Chemokine Microenvironment. Cancer Res. 2015, 75, 4766. [CrossRef] [PubMed]

26. El-Sherbiny, Y.M.; Meade, J.L.; Holmes, T.D.; McGonagle, D.; Mackie, S.L.; Morgan, A.W.; Cook, G.; Feyler, S.; Richards, S.J.; Davies, F.E.; et al. The Requirement for DNAM-1, NKG2D, and NKp46 in the Natural Killer Cell-Mediated Killing of Myeloma Cells. Cancer Res. 2007, 67, 8444. [CrossRef] [PubMed]

27. Carbone, E.; Neri, P.; Mesuraca, M.; Fulciniti, M.T.; Otsuki, T.; Pende, D.; Groh, V.; Spies, T.; Pollio, G.; Cosman, D.; et al. HLA Class I, NKG2D, and Natural Cytotoxicity Receptors Regulate Multiple Myeloma Cell Recognition by Natural Killer Cells. Blood 2005, 105, 251-258. [CrossRef]

28. Pazina, T.; MacFarlane, A.W., 4th; Bernabei, L.; Dulaimi, E.; Kotcher, R.; Yam, C.; Bezman, N.A.; Robbins, M.D.; Ross, E.A.; Campbell, K.S.; et al. Alterations of NK Cell Phenotype in the Disease Course of Multiple Myeloma. Cancers 2021, 13, 226. [CrossRef]

29. Pittari, G.; Vago, L.; Festuccia, M.; Bonini, C.; Mudawi, D.; Giaccone, L.; Bruno, B. Restoring Natural Killer Cell Immunity against Multiple Myeloma in the Era of New Drugs. Front. Immunol. 2017, 8, 1444. [CrossRef]

30. Leone, P.; Solimando, A.G.; Malerba, E.; Fasano, R.; Buonavoglia, A.; Pappagallo, F.; De Re, V.; Argentiero, A.; Silvestris, N.; Vacca, A.; et al. Actors on the Scene: Immune Cells in the Myeloma Niche. Front. Oncol. 2020, 10, 599098. [CrossRef] [PubMed]

31. Greil, C.; Engelhardt, M.; Ihorst, G.; Schoeller, K.; Bertz, H.; Marks, R.; Zeiser, R.; Duyster, J.; Einsele, H.; Finke, J.; et al. Allogeneic Transplantation of Multiple Myeloma Patients May Allow Long-Term Survival in Carefully Selected Patients with Acceptable Toxicity and Preserved Quality of Life. Haematologica 2019, 104, 370-379. [CrossRef] [PubMed]

32. Copelan, E.A. Hematopoietic Stem-Cell Transplantation. N. Engl. J. Med. 2006, 354, 1813-1826. [CrossRef] [PubMed]

33. Spierings, E.; Kim, Y.-H.; Hendriks, M.; Borst, E.; Sergeant, R.; Canossi, A.; Oudshoorn, M.; Loiseau, P.; Dolstra, H.; Markiewicz, M.; et al. Multicenter Analyses Demonstrate Significant Clinical Effects of Minor Histocompatibility Antigens on GvHD and GvL after HLA-Matched Related and Unrelated Hematopoietic Stem Cell Transplantation. Biol. Blood Marrow Transplant. 2013, 19, 1244-1253. [CrossRef] [PubMed]

34. Goulmy, E. Minor Histocompatibility Antigens: From Transplantation Problems to Therapy of Cancer. Hum. Immunol. 2006, 67, 433-438. [CrossRef] [PubMed] 
35. Oostvogels, R.; Lokhorst, H.M.; Mutis, T. Minor Histocompatibility Ags: Identification Strategies, Clinical Results and Translational Perspectives. Bone Marrow Transplant. 2016, 51, 163-171. [CrossRef] [PubMed]

36. Warren, E.H.; Fujii, N.; Akatsuka, Y.; Chaney, C.N.; Mito, J.K.; Loeb, K.R.; Gooley, T.A.; Brown, M.L.; Koo, K.K.W.; Rosinski, K.V.; et al. Therapy of Relapsed Leukemia after Allogeneic Hematopoietic Cell Transplantation with T Cells Specific for Minor Histocompatibility Antigens. Blood 2010, 115, 3869-3878. [CrossRef]

37. Franssen, L.E.; Roeven, M.W.H.; Hobo, W.; Doorn, R.; Oostvogels, R.; Falkenburg, J.H.F.; van de Donk, N.W.; Kester, M.G.D.; Fredrix, H.; Westinga, K.; et al. A Phase I/II Minor Histocompatibility Antigen-Loaded Dendritic Cell Vaccination Trial to Safely Improve the Efficacy of Donor Lymphocyte Infusions in Myeloma. Bone Marrow Transplant. 2017, 52, 1378-1383. [CrossRef]

38. Oostvogels, R.; Kneppers, E.; Minnema, M.C.; Doorn, R.C.; Franssen, L.E.; Aarts, T.; Emmelot, M.E.; Spierings, E.; SlaperCortenbach, I.; Westinga, K.; et al. Efficacy of Host-Dendritic Cell Vaccinations with or without Minor Histocompatibility Antigen Loading, Combined with Donor Lymphocyte Infusion in Multiple Myeloma Patients. Bone Marrow Transplant. 2017, 52, $228-237$. [CrossRef]

39. Garfall, A.L.; Stadtmauer, E.A. Cellular and Vaccine Immunotherapy for Multiple Myeloma. Hematol. Am. Soc. Hematol Educ. Program. 2016, 2016, 521-527. [CrossRef]

40. Rosenblatt, J.; Avivi, I.; Vasir, B.; Uhl, L.; Munshi, N.C.; Katz, T.; Dey, B.R.; Somaiya, P.; Mills, H.; Campigotto, F.; et al. Vaccination with Dendritic Cell/Tumor Fusions Following Autologous Stem Cell Transplant Induces Immunologic and Clinical Responses in Multiple Myeloma Patients. Clin. Cancer Res. 2013, 19, 3640. [CrossRef]

41. Hobo, W.; Strobbe, L.; Maas, F.; Fredrix, H.; Greupink-Draaisma, A.; Esendam, B.; de Witte, T.; Preijers, F.; Levenga, H.; van Rees, B.; et al. Immunogenicity of Dendritic Cells Pulsed with MAGE3, Survivin and B-Cell Maturation Antigen MRNA for Vaccination of Multiple Myeloma Patients. Cancer Immunol. Immunother. 2013, 62, 1381-1392. [CrossRef]

42. Palucka, K.; Banchereau, J. Dendritic-Cell-Based Therapeutic Cancer Vaccines. Immunity 2013, 39, 38-48. [CrossRef] [PubMed]

43. Dranoff, G. GM-CSF-Based Cancer Vaccines. Immunol. Rev. 2002, 188, 147-154. [CrossRef] [PubMed]

44. Borrello, I.M.; Noonan, K.; Huff, C.A.; Ferguson, A.; Sidorski, A.; Rudraraju, L.; Cimbro, R.; Marchionni, L. Allogeneic Myeloma GVAX with Lenalidomide Enhances Progression Free Survival through the Generation of Tumor Specific Immunity in Patients in Near Complete Remission. Blood 2015, 126, 4238. [CrossRef]

45. Weinstock, M.; Rosenblatt, J.; Avigan, D. Dendritic Cell Therapies for Hematologic Malignancies. Mol. Ther. - Methods Clin. Dev. 2017, 5, 66-75. [CrossRef]

46. Wong, K.K.; Hassan, R.; Yaacob, N.S. Hypomethylating Agents and Immunotherapy: Therapeutic Synergism in Acute Myeloid Leukemia and Myelodysplastic Syndromes. Front. Oncol. 2021, 11, 72. [CrossRef] [PubMed]

47. Nooka, A.K.; Wang, M. (Luhua); Yee, A.J.; Kaufman, J.L.; Bae, J.; Peterkin, D.; Richardson, P.G.; Raje, N.S. Assessment of Safety and Immunogenicity of PVX-410 Vaccine With or Without Lenalidomide in Patients With Smoldering Multiple Myeloma: A Nonrandomized Clinical Trial. JAMA Oncol. 2018, 4, e183267. [CrossRef]

48. Blass, E.; Ott, P.A. Advances in the Development of Personalized Neoantigen-Based Therapeutic Cancer Vaccines. Nat. Rev. Clin. Oncol. 2021, 18, 215-229. [CrossRef] [PubMed]

49. Ott, P.A.; Hu, Z.; Keskin, D.B.; Shukla, S.A.; Sun, J.; Bozym, D.J.; Zhang, W.; Luoma, A.; Giobbie-Hurder, A.; Peter, L.; et al. An Immunogenic Personal Neoantigen Vaccine for Patients with Melanoma. Nature 2017, 547, 217-221. [CrossRef]

50. Keskin, D.B.; Anandappa, A.J.; Sun, J.; Tirosh, I.; Mathewson, N.D.; Li, S.; Oliveira, G.; Giobbie-Hurder, A.; Felt, K.; Gjini, E.; et al. Neoantigen Vaccine Generates Intratumoral T Cell Responses in Phase Ib Glioblastoma Trial. Nature 2019, 565, 234-239. [CrossRef]

51. Perumal, D.; Imai, N.; Laganà, A.; Finnigan, J.; Melnekoff, D.; Leshchenko, V.V.; Solovyov, A.; Madduri, D.; Chari, A.; Cho, H.J.; et al. Mutation-Derived Neoantigen-Specific T-Cell Responses in Multiple Myeloma. Clin. Cancer Res. 2020, 26, 450. [CrossRef] [PubMed]

52. Rosenberg, S.A. Cell Transfer Immunotherapy for Metastatic Solid Cancer-What Clinicians Need to Know. Nat. Rev. Clin. Oncol 2011, 8, 577-585. [CrossRef] [PubMed]

53. Rosenberg, S.A.; Yang, J.C.; Sherry, R.M.; Kammula, U.S.; Hughes, M.S.; Phan, G.Q.; Citrin, D.E.; Restifo, N.P.; Robbins, P.F.; Wunderlich, J.R.; et al. Durable Complete Responses in Heavily Pretreated Patients with Metastatic Melanoma Using T-Cell Transfer Immunotherapy. Clin. Cancer Res. 2011, 17, 4550-4557. [CrossRef] [PubMed]

54. Dhodapkar, M.V.; Krasovsky, J.; Olson, K. T Cells from the Tumor Microenvironment of Patients with Progressive Myeloma Can Generate Strong, Tumor-Specific Cytolytic Responses to Autologous, Tumor-Loaded Dendritic Cells. Proc. Natl. Acad. Sci. USA 2002, 99, 13009-13013. [CrossRef]

55. Noonan, K.; Matsui, W.; Serafini, P.; Carbley, R.; Tan, G.; Khalili, J.; Bonyhadi, M.; Levitsky, H.; Whartenby, K.; Borrello, I. Activated Marrow-Infiltrating Lymphocytes Effectively Target Plasma Cells and Their Clonogenic Precursors. Cancer Res. 2005, 65, 2026. [CrossRef]

56. Lu, Y.-C.; Yao, X.; Crystal, J.S.; Li, Y.F.; El-Gamil, M.; Gross, C.; Davis, L.; Dudley, M.E.; Yang, J.C.; Samuels, Y.; et al. Efficient Identification of Mutated Cancer Antigens Recognized by T Cells Associated with Durable Tumor Regressions. Clin. Cancer Res. 2014, 20, 3401. [CrossRef]

57. Tran, E.; Turcotte, S.; Gros, A.; Robbins, P.F.; Lu, Y.-C.; Dudley, M.E.; Wunderlich, J.R.; Somerville, R.P.; Hogan, K.; Hinrichs, C.S.; et al. Cancer Immunotherapy Based on Mutation-Specific CD4+ T Cells in a Patient with Epithelial Cancer. Science 2014, $344,641$. [CrossRef] 
58. Tran, E.; Robbins, P.F.; Lu, Y.-C.; Prickett, T.D.; Gartner, J.J.; Jia, L.; Pasetto, A.; Zheng, Z.; Ray, S.; Groh, E.M.; et al. T-Cell Transfer Therapy Targeting Mutant KRAS in Cancer. N. Engl. J. Med. 2016, 375, 2255-2262. [CrossRef]

59. Alexandrov, L.B.; Nik-Zainal, S.; Wedge, D.C.; Aparicio, S.A.J.R.; Behjati, S.; Biankin, A.V.; Bignell, G.R.; Bolli, N.; Borg, A.; Børresen-Dale, A.-L.; et al. Signatures of Mutational Processes in Human Cancer. Nature 2013, 500, 415-421. [CrossRef]

60. Lawrence, M.S.; Stojanov, P.; Polak, P.; Kryukov, G.V.; Cibulskis, K.; Sivachenko, A.; Carter, S.L.; Stewart, C.; Mermel, C.H.; Roberts, S.A.; et al. Mutational Heterogeneity in Cancer and the Search for New Cancer-Associated Genes. Nature 2013, 499, 214-218. [CrossRef]

61. Noonan, K.A.; Huff, C.A.; Davis, J.; Lemas, M.V.; Fiorino, S.; Bitzan, J.; Ferguson, A.; Emerling, A.; Luznik, L.; Matsui, W.; et al. Adoptive Transfer of Activated Marrow-Infiltrating Lymphocytes Induces Measurable Antitumor Immunity in the Bone Marrow in Multiple Myeloma. Sci Transl Med. 2015, 7, 288ra78. [CrossRef] [PubMed]

62. Scheper, W.; Kelderman, S.; Fanchi, L.F.; Linnemann, C.; Bendle, G.; de Rooij, M.A.J.; Hirt, C.; Mezzadra, R.; Slagter, M.; Dijkstra, K.; et al. Low and Variable Tumor Reactivity of the Intratumoral TCR Repertoire in Human Cancers. Nat. Med. 2019, $25,89-94$. [CrossRef] [PubMed]

63. Li, Q.; Ding, Z.-Y. The Ways of Isolating Neoantigen-Specific T Cells. Front. Oncol 2020, 10, 1347. [CrossRef] [PubMed]

64. Lokhorst, H.M.; Schattenberg, A.; Cornelissen, J.J.; van Oers, M.H.J.; Fibbe, W.; Russell, I.; Donk, N.W.C.J.v.d.; Verdonck, L.F. Donor Lymphocyte Infusions for Relapsed Multiple Myeloma After Allogeneic Stem-Cell Transplantation: Predictive Factors for Response and Long-Term Outcome. JCO 2000, 18, 3031-3037. [CrossRef]

65. Beitinjaneh, A.M.; Saliba, R.; Bashir, Q.; Shah, N.; Parmar, S.; Hosing, C.; Popat, U.; Anderlini, P.; Dinh, Y.; Qureshi, S.; et al. Durable Responses after Donor Lymphocyte Infusion for Patients with Residual Multiple Myeloma Following Non-Myeloablative Allogeneic Stem Cell Transplant. null 2012, 53, 1525-1529. [CrossRef]

66. Simonetta, F.; Alvarez, M.; Negrin, R.S. Natural Killer Cells in Graft-versus-Host-Disease after Allogeneic Hematopoietic Cell Transplantation. Front. Immunol 2017, 8, 465. [CrossRef]

67. Caligiuri, M.A. Human Natural Killer Cells. Blood 2008, 112, 461-469. [CrossRef]

68. Jurisic, V.; Srdic, T.; Konjevic, G.; Markovic, O.; Colovic, M. Clinical Stage-Depending Decrease of NK Cell Activity in Multiple Myeloma Patients. Med. Oncol. 2007, 24, 312-317. [CrossRef]

69. Fauriat, C.; Mallet, F.; Olive, D.; Costello, R.T. Impaired Activating Receptor Expression Pattern in Natural Killer Cells from Patients with Multiple Myeloma. Leukemia 2006, 20, 732-733. [CrossRef]

70. Costello, R.T.; Boehrer, A.; Sanchez, C.; Mercier, D.; Baier, C.; Le Treut, T.; Sébahoun, G. Differential Expression of Natural Killer Cell Activating Receptors in Blood versus Bone Marrow in Patients with Monoclonal Gammopathy. Immunology 2013, 139, 338-341. [CrossRef]

71. Shi, J.; Tricot, G.; Szmania, S.; Rosen, N.; Garg, T.K.; Malaviarachchi, P.A.; Moreno, A.; Dupont, B.; Hsu, K.C.; Baxter-Lowe, L.A.; et al. Infusion of Haplo-Identical Killer Immunoglobulin-like Receptor Ligand Mismatched NK Cells for Relapsed Myeloma in the Setting of Autologous Stem Cell Transplantation. Br. J. Haematol 2008, 143, 641-653. [CrossRef]

72. Ruggeri, L.; Capanni, M.; Urbani, E.; Perruccio, K.; Shlomchik, W.D.; Tosti, A.; Posati, S.; Rogaia, D.; Frassoni, F.; Aversa, F.; et al. Effectiveness of Donor Natural Killer Cell Alloreactivity in Mismatched Hematopoietic Transplants. Science 2002, $295,2097$. [CrossRef] [PubMed]

73. Single, R.M.; Martin, M.P.; Gao, X.; Meyer, D.; Yeager, M.; Kidd, J.R.; Kidd, K.K.; Carrington, M. Global Diversity and Evidence for Coevolution of KIR and HLA. Nat. Genet. 2007, 39, 1114-1119. [CrossRef]

74. Miller, J.S.; Soignier, Y.; Panoskaltsis-Mortari, A.; McNearney, S.A.; Yun, G.H.; Fautsch, S.K.; McKenna, D.; Le, C.; Defor, T.E.; Burns, L.J.; et al. Successful Adoptive Transfer and in Vivo Expansion of Human Haploidentical NK Cells in Patients with Cancer. Blood 2005, 105, 3051-3057. [CrossRef] [PubMed]

75. Tricot, G.; Vesole, D.H.; Jagannath, S.; Hilton, J.; Munshi, N.; Barlogie, B. Graft-Versus-Myeloma Effect: Proof of Principle. Blood 1996, 87, 1196-1198. [CrossRef] [PubMed]

76. Shah, N.; Li, L.; McCarty, J.; Kaur, I.; Yvon, E.; Shaim, H.; Muftuoglu, M.; Liu, E.; Orlowski, R.Z.; Cooper, L.; et al. Phase I Study of Cord Blood-Derived Natural Killer Cells Combined with Autologous Stem Cell Transplantation in Multiple Myeloma. Br. J. Haematol 2017, 177, 457-466. [CrossRef]

77. Shah, N.; Mehta, R.; Li, L.; Mccarty, J.; Kaur, I.; Orlowski, R.Z.; Cooper, L.; Lee, D.A.; Cao, K.; Parmar, S.; et al. Phase II Study of Ex Vivo Expanded Cord Blood Natural Killer Cells for Multiple Myeloma. JCO 2018, 36, 8006. [CrossRef]

78. Hagner, P.R.; Chiu, H.; Ortiz, M.; Apollonio, B.; Wang, M.; Couto, S.; Waldman, M.F.; Flynt, E.; Ramsay, A.G.; Trotter, M.; et al. Activity of Lenalidomide in Mantle Cell Lymphoma Can Be Explained by NK Cell-Mediated Cytotoxicity. Br. J. Haematol. 2017, 179, 399-409. [CrossRef]

79. Hsu, A.K.; Quach, H.; Tai, T.; Prince, H.M.; Harrison, S.J.; Trapani, J.A.; Smyth, M.J.; Neeson, P.; Ritchie, D.S. The Immunostimulatory Effect of Lenalidomide on NK-Cell Function Is Profoundly Inhibited by Concurrent Dexamethasone Therapy. Blood 2011, 117, 1605-1613. [CrossRef]

80. Lokhorst, H.M.; Plesner, T.; Laubach, J.P.; Nahi, H.; Gimsing, P.; Hansson, M.; Minnema, M.C.; Lassen, U.; Krejcik, J.; Palumbo, A.; et al. Targeting CD38 with Daratumumab Monotherapy in Multiple Myeloma. N. Engl. J. Med. 2015, 373, 1207-1219. [CrossRef]

81. Casneuf, T.; Xu, X.S.; Adams, H.C., 3rd; Axel, A.E.; Chiu, C.; Khan, I.; Ahmadi, T.; Yan, X.; Lonial, S.; Plesner, T.; et al. Effects of Daratumumab on Natural Killer Cells and Impact on Clinical Outcomes in Relapsed or Refractory Multiple Myeloma. Blood Adv. 2017, 1, 2105-2114. [CrossRef] 
82. Naeimi Kararoudi, M.; Nagai, Y.; Elmas, E.; de Souza Fernandes Pereira, M.; Ali, S.A.; Imus, P.H.; Wethington, D.; Borrello, I.M.; Lee, D.A.; Ghiaur, G. CD38 Deletion of Human Primary NK Cells Eliminates Daratumumab-Induced Fratricide and Boosts Their Effector Activity. Blood 2020, 136, 2416-2427. [CrossRef]

83. Rosenberg, S.A.; Restifo, N.P. Adoptive Cell Transfer as Personalized Immunotherapy for Human Cancer. Science 2015, $348,62$. [CrossRef]

84. June, C.H.; Sadelain, M. Chimeric Antigen Receptor Therapy. N. Engl. J. Med. 2018, 379, 64-73. [CrossRef]

85. Albinger, N.; Hartmann, J.; Ullrich, E. Current Status and Perspective of CAR-T and CAR-NK Cell Therapy Trials in Germany. Gene Ther. 2021. [CrossRef]

86. Bishop, D.C.; Clancy, L.E.; Simms, R.; Burgess, J.; Mathew, G.; Moezzi, L.; Street, J.A.; Sutrave, G.; Atkins, E.; McGuire, H.M.; et al. Development of CAR T-Cell Lymphoma in Two of Ten Patients Effectively Treated with PiggyBac Modified CD19 CAR T-Cells. Blood 2021. [CrossRef]

87. Johnson, L.A.; Morgan, R.A.; Dudley, M.E.; Cassard, L.; Yang, J.C.; Hughes, M.S.; Kammula, U.S.; Royal, R.E.; Sherry, R.M.; Wunderlich, J.R.; et al. Gene Therapy with Human and Mouse T-Cell Receptors Mediates Cancer Regression and Targets Normal Tissues Expressing Cognate Antigen. Blood 2009, 114, 535-546. [CrossRef] [PubMed]

88. Van de Donk, N.W.C.J.; Richardson, P.G.; Malavasi, F. CD38 Antibodies in Multiple Myeloma: Back to the Future. Blood 2018, 131, 13-29. [CrossRef] [PubMed]

89. Guo, Y.; Feng, K.; Tong, C.; Jia, H.; Liu, Y.; Wang, Y.; Ti, D.; Yang, Q.; Wu, Z.; Han, W. Efficiency and Side Effects of Anti-CD38 CAR T Cells in an Adult Patient with Relapsed B-ALL after Failure of Bi-Specific CD19/CD22 CAR T Cell Treatment. Cell. Mol. Immunol. 2020, 17, 430-432. [CrossRef]

90. Rapoport, A.P.; Stadtmauer, E.A.; Binder-Scholl, G.K.; Goloubeva, O.; Vogl, D.T.; Lacey, S.F.; Badros, A.Z.; Garfall, A.; Weiss, B.; Finklestein, J.; et al. NY-ESO-1-Specific TCR-Engineered T Cells Mediate Sustained Antigen-Specific Antitumor Effects in Myeloma. Nat. Med. 2015, 21, 914-921. [CrossRef] [PubMed]

91. Stadtmauer, E.A.; Fraietta, J.A.; Davis, M.M.; Cohen, A.D.; Weber, K.L.; Lancaster, E.; Mangan, P.A.; Kulikovskaya, I.; Gupta, M.; Chen, F.; et al. CRISPR-Engineered T Cells in Patients with Refractory Cancer. Science 2020, 367, eaba7365. [CrossRef] [PubMed]

92. Majzner, R.G.; Mackall, C.L. Tumor Antigen Escape from CAR T-Cell Therapy. Cancer Discov. 2018, 8, 1219. [CrossRef] [PubMed]

93. O'Connor, B.P.; Raman, V.S.; Erickson, L.D.; Cook, W.J.; Weaver, L.K.; Ahonen, C.; Lin, L.-L.; Mantchev, G.T.; Bram, R.J.; Noelle, R.J. BCMA Is Essential for the Survival of Long-Lived Bone Marrow Plasma Cells. J. Exp. Med. 2004, 199, 91-98. [CrossRef] [PubMed]

94. Drent, E.; Themeli, M.; Poels, R.; de Jong-Korlaar, R.; Yuan, H.; de Bruijn, J.; Martens, A.C.M.; Zweegman, S.; van de Donk, N.W.C.J.; Groen, R.W.J.; et al. A Rational Strategy for Reducing On-Target Off-Tumor Effects of CD38-Chimeric Antigen Receptors by Affinity Optimization. Mol. Ther. 2017, 25, 1946-1958. [CrossRef]

95. Van de Donk, N.W.C.J.; Usmani, S.Z.; Yong, K. CAR T-Cell Therapy for Multiple Myeloma: State of the Art and Prospects. Lancet Haematol. 2021, 8, e446-e461. [CrossRef]

96. Teoh, P.J.; Chng, W.J. CAR T-Cell Therapy in Multiple Myeloma: More Room for Improvement. Blood Cancer J. 2021, 11, 84. [CrossRef]

97. First CAR-T Therapy to Target BCMA Gets FDA Nod. Nat. Biotechnol. 2021, 39, 531. [CrossRef]

98. Munshi, N.C.; Anderson, L.D.; Shah, N.; Madduri, D.; Berdeja, J.; Lonial, S.; Raje, N.; Lin, Y.; Siegel, D.; Oriol, A.; et al. Idecabtagene Vicleucel in Relapsed and Refractory Multiple Myeloma. N. Engl. J. Med. 2021, 384, 705-716. [CrossRef]

99. Berdeja, J.G.; Madduri, D.; Usmani, S.Z.; Jakubowiak, A.; Agha, M.; Cohen, A.D.; Stewart, A.K.; Hari, P.; Htut, M.; Lesokhin, A.; et al. Ciltacabtagene Autoleucel, a B-Cell Maturation Antigen-Directed Chimeric Antigen Receptor T-Cell Therapy in Patients with Relapsed or Refractory Multiple Myeloma (CARTITUDE-1): A Phase 1b/2 Open-Label Study. The Lancet 2021, 398, 314-324. [CrossRef]

100. Da Vià, M.C.; Dietrich, O.; Truger, M.; Arampatzi, P.; Duell, J.; Heidemeier, A.; Zhou, X.; Danhof, S.; Kraus, S.; Chatterjee, M.; et al. Homozygous BCMA Gene Deletion in Response to Anti-BCMA CAR T Cells in a Patient with Multiple Myeloma. Nat. Med. 2021, 27, 616-619. [CrossRef]

101. Samur, M.K.; Fulciniti, M.; Aktas-Samur, A.; Bazarbachi, A.H.; Tai, Y.-T.; Campbell, T.B.; Petrocca, F.; Hege, K.; Kaiser, S.; Anderson, K.; et al. Biallelic Loss of BCMA Triggers Resistance to Anti-BCMA CAR T Cell Therapy in Multiple Myeloma. Blood 2020, 136, 14. [CrossRef]

102. Shah, N.N.; Fry, T.J. Mechanisms of Resistance to CAR T Cell Therapy. Nat. Rev. Clin. Oncol. 2019, 16, 372-385. [CrossRef]

103. McLellan, A.D.; Ali Hosseini Rad, S.M. Chimeric Antigen Receptor T Cell Persistence and Memory Cell Formation. Immunol. Cell Biol. 2019, 97, 664-674. [CrossRef]

104. Zah, E. Systematically Optimized BCMA/CS1 Bispecific CAR-T Cells Robustly Control Heterogeneous Multiple Myeloma. Nat. Commun. 2020, 11, 1-13. [CrossRef]

105. Fernández de Larrea, C.; Staehr, M.; Lopez, A.V.; Ng, K.Y.; Chen, Y.; Godfrey, W.D.; Purdon, T.J.; Ponomarev, V.; Wendel, H.-G.; Brentjens, R.J.; et al. Defining an Optimal Dual-Targeted CAR T-Cell Therapy Approach Simultaneously Targeting BCMA and GPRC5D to Prevent BCMA Escape-Driven Relapse in Multiple Myeloma. Blood Cancer Discov 2020, 1, 146. [CrossRef]

106. Schmidts, A.; Ormhøj, M.; Choi, B.D.; Taylor, A.O.; Bouffard, A.A.; Scarfò, I.; Larson, R.C.; Frigault, M.J.; Gallagher, K.; Castano, A.P.; et al. Rational Design of a Trimeric APRIL-Based CAR-Binding Domain Enables Efficient Targeting of Multiple Myeloma. Blood Adv. 2019, 3, 3248-3260. [CrossRef] 
107. Ayuk, F.; Fehse, B.; Janson, D.; Berger, C.; Riecken, K.; Kröger, N. Excellent Proliferation and Persistence of Allogeneic DonorDerived 41-BB Based CAR-T Cells despite Immunosuppression with Cyclosporine A. Haematologica 2020, 105, 322-324. [CrossRef]

108. Depil, S.; Duchateau, P.; Grupp, S.A.; Mufti, G.; Poirot, L. ‘Off-the-Shelf’ Allogeneic CAR T Cells: Development and Challenges. Nat. Rev. Drug Discov. 2020, 19, 185-199. [CrossRef]

109. Liu, E.; Marin, D.; Banerjee, P.; Macapinlac, H.A.; Thompson, P.; Basar, R.; Nassif Kerbauy, L.; Overman, B.; Thall, P.; Kaplan, M.; et al. Use of CAR-Transduced Natural Killer Cells in CD19-Positive Lymphoid Tumors. N. Engl. J. Med. 2020, 382, 545-553. [CrossRef]

110. Zhang, C.; Oberoi, P.; Oelsner, S.; Waldmann, A.; Lindner, A.; Tonn, T.; Wels, W.S. Chimeric Antigen Receptor-Engineered NK-92 Cells: An Off-the-Shelf Cellular Therapeutic for Targeted Elimination of Cancer Cells and Induction of Protective Antitumor Immunity. Front. Immunol. 2017, 8, 533. [CrossRef]

111. Wrona, E.; Borowiec, M.; Potemski, P. CAR-NK Cells in the Treatment of Solid Tumors. Int. J. Mol. Sci. 2021, 22, 5899. [CrossRef] [PubMed]

112. Zhu, Y.X.; Braggio, E.; Shi, C.-X.; Kortuem, K.M.; Bruins, L.A.; Schmidt, J.E.; Chang, X.-B.; Langlais, P.; Luo, M.; Jedlowski, P.; et al. Identification of Cereblon-Binding Proteins and Relationship with Response and Survival after IMiDs in Multiple Myeloma. Blood 2014, 124, 536-545. [CrossRef] [PubMed]

113. Krönke, J.; Udeshi, N.D.; Narla, A.; Grauman, P.; Hurst, S.N.; McConkey, M.; Svinkina, T.; Heckl, D.; Comer, E.; Li, X.; et al. Lenalidomide Causes Selective Degradation of IKZF1 and IKZF3 in Multiple Myeloma Cells. Science 2014, 343, 301-305. [CrossRef] [PubMed]

114. Lu, G.; Middleton, R.E.; Sun, H.; Naniong, M.; Ott, C.J.; Mitsiades, C.S.; Wong, K.-K.; Bradner, J.E.; Kaelin, W.G., Jr. The Myeloma Drug Lenalidomide Promotes the Cereblon-Dependent Destruction of Ikaros Proteins. Science 2014, 343, 305-309. [CrossRef] [PubMed]

115. Kalia, V.; Sarkar, S. Regulation of Effector and Memory CD8 T Cell Differentiation by IL-2-A Balancing Act. Front. Immunol. 2018, 9, 2987. [CrossRef] [PubMed]

116. Nijhof, I.S.; Franssen, L.E.; Levin, M.-D.; Bos, G.M.J.; Broijl, A.; Klein, S.K.; Koene, H.R.; Bloem, A.C.; Beeker, A.; Faber, L.M.; et al. Phase 1/2 Study of Lenalidomide Combined with Low-Dose Cyclophosphamide and Prednisone in Lenalidomide-Refractory Multiple Myeloma. Blood 2016, 128, 2297-2306. [CrossRef]

117. Pasquier, E.; Kavallaris, M.; André, N. Metronomic Chemotherapy: New Rationale for New Directions. Nat. Rev. Clin. Oncol. 2010, 7, 455-465. [CrossRef]

118. Cerullo, V.; Diaconu, I.; Kangasniemi, L.; Rajecki, M.; Escutenaire, S.; Koski, A.; Romano, V.; Rouvinen, N.; Tuuminen, T.; Laasonen, L.; et al. Immunological Effects of Low-Dose Cyclophosphamide in Cancer Patients Treated With Oncolytic Adenovirus. Mol. Ther. 2011, 19, 1737-1746. [CrossRef] [PubMed]

119. Ge, Y.; Domschke, C.; Stoiber, N.; Schott, S.; Heil, J.; Rom, J.; Blumenstein, M.; Thum, J.; Sohn, C.; Schneeweiss, A.; et al. Metronomic Cyclophosphamide Treatment in Metastasized Breast Cancer Patients: Immunological Effects and Clinical Outcome. Cancer Immunol. Immunother. 2012, 61, 353-362. [CrossRef]

120. Ghiringhelli, F.; Larmonier, N.; Schmitt, E.; Parcellier, A.; Cathelin, D.; Garrido, C.; Chauffert, B.; Solary, E.; Bonnotte, B.; Martin, F. CD4+CD25+ Regulatory T Cells Suppress Tumor Immunity but Are Sensitive to Cyclophosphamide Which Allows Immunotherapy of Es-tablished Tumors to Be Curative. Eur. J. Immunol. 2004, 34, 336-344. [CrossRef]

121. Zhao, J.; Cao, Y.; Lei, Z.; Yang, Z.; Zhang, B.; Huang, B. Selective Depletion of CD $4^{+} \mathrm{CD} 25^{+}$Foxp $3^{+}$Regulatory T Cells by Low-Dose Cyclophosphamide Is Explained by Reduced Intracellular ATP Levels. Cancer Res. 2010, 70, 4850. [CrossRef] [PubMed]

122. Serrano-Del Valle, A.; Anel, A.; Naval, J.; Marzo, I. Immunogenic Cell Death and Immunotherapy of Multiple Myeloma. Front. Cell Dev. Biol. 2019, 7, 50. [CrossRef] [PubMed]

123. Maes, K.; Breckpot, K. Commentary: Immunogenic Cell Death and Immunotherapy of Multiple Myeloma. Front. Cell Dev. Biol 2019, 7, 149. [CrossRef]

124. Gulla, A.; Morelli, E.; Samur, M.K.; Botta, C.; Hideshima, T.; Bianchi, G.; Fulciniti, M.; Malvestiti, S.; Prabhala, R.H.; Talluri, S.; et al. Bortezomib Induces Anti-Multiple Myeloma Immune Response Mediated by CGAS/STING Pathway Activation. Blood Cancer Discov. 2021. [CrossRef]

125. Saba, R.; Saleem, N.; Peace, D. Long-Term Survival Consequent on the Abscopal Effect in a Patient with Multiple Myeloma. BMJ Case Rep. 2016, 2016, bcr2016215237. [CrossRef]

126. Craig, D.J.; Nanavaty, N.S.; Devanaboyina, M.; Stanbery, L.; Hamouda, D.; Edelman, G.; Dworkin, L.; Nemunaitis, J.J. The Abscopal Effect of Radiation Therapy. Future Oncol. 2021, 17, 1683-1694. [CrossRef] [PubMed]

127. Nijhof, I.S.; Casneuf, T.; van Velzen, J.; van Kessel, B.; Axel, A.E.; Syed, K.; Groen, R.W.J.; van Duin, M.; Sonneveld, P.; Minnema, M.C.; et al. CD38 Expression and Complement Inhibitors Affect Response and Resistance to Daratumumab Therapy in Myeloma. Blood 2016, 128, 959-970. [CrossRef] [PubMed]

128. Krejcik, J.; Frerichs, K.A.; Nijhof, I.S.; van Kessel, B.; van Velzen, J.F.; Bloem, A.C.; Broekmans, M.E.C.; Zweegman, S.; van Meerloo, J.; Musters, R.J.P.; et al. Monocytes and Granulocytes Reduce CD38 Expression Levels on Myeloma Cells in Patients Treated with Daratumumab. Clin. Cancer Res. 2017, 23, 7498. [CrossRef] [PubMed]

129. Krejcik, J.; van de Donk, N.W.C.J. Trogocytosis Represents a Novel Mechanism of Action of Daratumumab in Multiple Myeloma. Oncotarget 2018, 9, 33621-33622. [CrossRef] 
130. Plesner, T.; van de Donk, N.; Richardson, P.G. Controversy in the Use of CD38 Antibody for Treatment of Myeloma: Is High CD38 Expression Good or Bad? Cells 2020, 9, 378. [CrossRef]

131. Chen, L.; Diao, L.; Yang, Y.; Yi, X.; Rodriguez, B.L.; Li, Y.; Villalobos, P.A.; Cascone, T.; Liu, X.; Tan, L.; et al. CD38-Mediated Immunosuppression as a Mechanism of Tumor Cell Escape from PD-1/PD-L1 Blockade. Cancer Discov. 2018, 8, 1156. [CrossRef] [PubMed]

132. Quarona, V.; Ferri, V.; Chillemi, A.; Bolzoni, M.; Mancini, C.; Zaccarello, G.; Roato, I.; Morandi, F.; Marimpietri, D.; Faccani, G.; et al. Unraveling the Contribution of Ectoenzymes to Myeloma Life and Survival in the Bone Marrow Niche. Ann. N. Y. Acad. Sci. 2015, 1335, 10-22. [CrossRef] [PubMed]

133. Krejcik, J.; Casneuf, T.; Nijhof, I.S.; Verbist, B.; Bald, J.; Plesner, T.; Syed, K.; Liu, K.; van de Donk, N.W.C.J.; Weiss, B.M.; et al. Daratumumab Depletes CD38+ Immune Regulatory Cells, Promotes T-Cell Expansion, and Skews T-Cell Repertoire in Multiple Myeloma. Blood 2016, 128, 384-394. [CrossRef] [PubMed]

134. Dimopoulos, M.; Bringhen, S.; Anttila, P.; Capra, M.; Cavo, M.; Cole, C.; Gasparetto, C.; Hungria, V.; Jenner, M.; Vorobyev, V.; et al. Isatuximab as Monotherapy and Combined with Dexamethasone in Patients with Relapsed/Refractory Multiple Myeloma. Blood 2021, 137, 1154-1165. [CrossRef]

135. Atanackovic, D.; Yousef, S.; Shorter, C.; Tantravahi, S.K.; Steinbach, M.; Iglesias, F.; Sborov, D.; Radhakrishnan, S.V.; Chiron, M.; Miles, R.; et al. In Vivo Vaccination Effect in Multiple Myeloma Patients Treated with the Monoclonal Antibody Isatuximab. Leukemia 2020, 34, 317-321. [CrossRef]

136. Costa, F.; Marchica, V.; Storti, P.; Malavasi, F.; Giuliani, N. PD-L1/PD-1 Axis in Multiple Myeloma Microenvironment and a Possible Link with CD38-Mediated Immune-Suppression. Cancers 2021, 13, 164. [CrossRef] [PubMed]

137. Benson, D.M., Jr.; Bakan, C.E.; Mishra, A.; Hofmeister, C.C.; Efebera, Y.; Becknell, B.; Baiocchi, R.A.; Zhang, J.; Yu, J.; Smith, M.K.; et al. The PD-1/PD-L1 Axis Modulates the Natural Killer Cell versus Multiple Myeloma Effect: A Therapeutic Target for CT-011, a Novel Monoclonal Anti-PD-1 Antibody. Blood 2010, 116, 2286-2294. [CrossRef]

138. Görgün, G.; Samur, M.K.; Cowens, K.B.; Paula, S.; Bianchi, G.; Anderson, J.E.; White, R.E.; Singh, A.; Ohguchi, H.; Suzuki, R.; et al. Lenalidomide Enhances Immune Checkpoint Blockade-Induced Immune Response in Multiple Myeloma. Clin. Cancer Res. 2015, 21,4607-4618. [CrossRef]

139. Rosenblatt, J.; Avigan, D. Targeting the PD-1/PD-L1 Axis in Multiple Myeloma: A Dream or a Reality? Blood 2017, 129, 275-279. [CrossRef]

140. Verkleij, C.P.M.; Jhatakia, A.; Broekmans, M.E.C.; Frerichs, K.A.; Zweegman, S.; Mutis, T.; Bezman, N.A.; van de Donk, N.W.C.J. Preclinical Rationale for Targeting the PD-1/PD-L1 Axis in Combination with a CD38 Antibody in Multiple Myeloma and Other CD38-Positive Malignancies. Cancers (Basel) 2020, 12, 3713. [CrossRef]

141. Cohen, Y.C.; Oriol, A.; Wu, K.L.; Lavi, N.; Vlummens, P.; Jackson, C.; Garvin, W.; Carson, R.; Crist, W.; Fu, J.; et al. Daratumumab With Cetrelimab, an Anti-PD-1 Monoclonal Antibody, in Relapsed/Refractory Multiple Myeloma. Clin. Lymphoma Myeloma Leuk. 2021, 21, 46-54.e4. [CrossRef]

142. Mateos, M.-V.; Orlowski, R.Z.; Siegel, D.S.D.; Reece, D.E.; Moreau, P.; Ocio, E.M.; Shah, J.J.; Rodríguez-Otero, P.; Munshi, N.C.; Avigan, D.; et al. Pembrolizumab in Combination with Lenalidomide and Low-Dose Dexamethasone for Relapsed/Refractory Multiple Myeloma (RRMM): Final Efficacy and Safety Analysis. JCO 2016, 34, 8010. [CrossRef]

143. Zanwar, S.; Nandakumar, B.; Kumar, S. Immune-Based Therapies in the Management of Multiple Myeloma. Blood Cancer J. 2020, 10, 84. [CrossRef] [PubMed]

144. Mateos, M.-V.; Blacklock, H.; Schjesvold, F.; Oriol, A.; Simpson, D.; George, A.; Goldschmidt, H.; Larocca, A.; Chanan-Khan, A.; Sherbenou, D.; et al. Pembrolizumab plus Pomalidomide and Dexamethasone for Patients with Relapsed or Refractory Multiple Myeloma (KEYNOTE-183): A Randomised, Open-Label, Phase 3 Trial. Lancet Haematol. 2019, 6, e459-e469. [CrossRef]

145. Usmani, S.Z.; Schjesvold, F.; Oriol, A.; Karlin, L.; Cavo, M.; Rifkin, R.M.; Yimer, H.A.; LeBlanc, R.; Takezako, N.; McCroskey, R.D.; et al. Pembrolizumab plus Lenalidomide and Dexamethasone for Patients with Treatment-Naive Multiple Myeloma (KEYNOTE-185): A Randomised, Open-Label, Phase 3 Trial. Lancet Haematol. 2019, 6, e448-e458. [CrossRef]

146. Genmab Announces That Janssen Will Stop Studies of Daratumumab in Combination with Anti-PD-(L)1 - Genmab A/S. Available online: https://ir.genmab.com/news-releases/news-release-details/genmab-announces-janssen-will-stop-studiesdaratumumab (accessed on 23 June 2021).

147. Fraietta, J.A.; Lacey, S.F.; Orlando, E.J.; Pruteanu-Malinici, I.; Gohil, M.; Lundh, S.; Boesteanu, A.C.; Wang, Y.; O'Connor, R.S.; Hwang, W.-T.; et al. Determinants of Response and Resistance to CD19 Chimeric Antigen Receptor (CAR) T Cell Therapy of Chronic Lymphocytic Leukemia. Nat. Med. 2018, 24, 563-571. [CrossRef]

148. Zolov, S.N.; Rietberg, S.P.; Bonifant, C.L. Programmed Cell Death Protein 1 Activation Preferentially Inhibits CD28.CAR-T Cells. Cytotherapy 2018, 20, 1259-1266. [CrossRef]

149. Galon, J.; Rossi, J.; Turcan, S.; Danan, C.; Locke, F.L.; Neelapu, S.S.; Miklos, D.B.; Bartlett, N.L.; Jacobson, C.A.; Braunschweig, I.; et al. Characterization of Anti-CD19 Chimeric Antigen Receptor (CAR) T Cell-Mediated Tumor Microenvironment Immune Gene Profile in a Multicenter Trial (ZUMA-1) with Axicabtagene Ciloleucel (Axi-Cel, KTE-C19). JCO 2017, 35, 3025. [CrossRef]

150. Bernabei, L.; Garfall, A.L.; Melenhorst, J.J.; Lacey, S.F.; Stadtmauer, E.A.; Vogl, D.T.; Gonzalez, V.; Plesa, G.; Young, R.M.; Waxman, A.; et al. PD-1 Inhibitor Combinations As Salvage Therapy for Relapsed/Refractory Multiple Myeloma (MM) Patients Progressing after Bcma-Directed CAR T Cells. Blood 2018, 132, 1973. [CrossRef] 
151. Wudhikarn, K.; Mailankody, S.; Smith, E.L. Future of CAR T Cells in Multiple Myeloma. Hematol. Am. Soc. Hematol Educ Program. 2020, 2020, 272-279. [CrossRef]

152. Suarez, E.R.; Chang, D.K.; Sun, J.; Sui, J.; Freeman, G.J.; Signoretti, S.; Zhu, Q.; Marasco, W.A. Chimeric Antigen Receptor T Cells Secreting Anti-PD-L1 Antibodies More Effectively Regress Renal Cell Carcinoma in a Humanized Mouse Model. Oncotarget 2016, 7, 34341-34355. [CrossRef] [PubMed]

153. Rafiq, S.; Yeku, O.O.; Jackson, H.J.; Purdon, T.J.; van Leeuwen, D.G.; Drakes, D.J.; Song, M.; Miele, M.M.; Li, Z.; Wang, P.; et al. Targeted Delivery of a PD-1-Blocking ScFv by CAR-T Cells Enhances Anti-Tumor Efficacy in Vivo. Nat. Biotechnol. 2018, 36, 847-856. [CrossRef]

154. Zhang, C.; Peng, Y.; Hublitz, P.; Zhang, H.; Dong, T. Genetic Abrogation of Immune Checkpoints in Antigen-Specific Cytotoxic T-Lymphocyte as a Potential Alternative to Blockade Immunotherapy. Sci. Rep. 2018, 8, 5549. [CrossRef]

155. Advani, R.; Flinn, I.; Popplewell, L.; Forero, A.; Bartlett, N.L.; Ghosh, N.; Kline, J.; Roschewski, M.; LaCasce, A.; Collins, G.P.; et al. CD47 Blockade by Hu5F9-G4 and Rituximab in Non-Hodgkin's Lymphoma. N. Engl. J. Med. 2018, 379, 1711-1721. [CrossRef]

156. Chao, M.P.; Alizadeh, A.A.; Tang, C.; Myklebust, J.H.; Varghese, B.; Gill, S.; Jan, M.; Cha, A.C.; Chan, C.K.; Tan, B.T.; et al. Anti-CD47 Antibody Synergizes with Rituximab to Promote Phagocytosis and Eradicate Non-Hodgkin Lymphoma. Cell 2010, 142, 699-713. [CrossRef] [PubMed]

157. Tseng, D.; Volkmer, J.-P.; Willingham, S.B.; Contreras-Trujillo, H.; Fathman, J.W.; Fernhoff, N.B.; Seita, J.; Inlay, M.A.; Weiskopf, K.; Miyanishi, M.; et al. Anti-CD47 Antibody-Mediated Phagocytosis of Cancer by Macrophages Primes an Effective Antitumor T-Cell Response. Proc. Natl. Acad. Sci. USA 2013, 110, 11103. [CrossRef] [PubMed]

158. Storti, P.; Vescovini, R.; Costa, F.; Marchica, V.; Toscani, D.; Dalla Palma, B.; Craviotto, L.; Malavasi, F.; Giuliani, N. CD14+CD16+ Monocytes Are Involved in Daratumumab-Mediated Myeloma Cells Killing and in Anti-CD47 Therapeutic Strategy. Br. J. Haematol. 2020, 190, 430-436. [CrossRef] [PubMed]

159. Khair, D.O.; Bax, H.J.; Mele, S.; Crescioli, S.; Pellizzari, G.; Khiabany, A.; Nakamura, M.; Harris, R.J.; French, E.; Hoffmann, R.M.; et al. Combining Immune Checkpoint Inhibitors: Established and Emerging Targets and Strategies to Improve Outcomes in Melanoma. Front. Immunol. 2019, 10, 453. [CrossRef] [PubMed]

160. Zhou, X.; Einsele, H.; Danhof, S. Bispecific Antibodies: A New Era of Treatment for Multiple Myeloma. J. Clin. Med. 2020, 9, 2166. [CrossRef]

161. Brinkmann, U.; Kontermann, R.E. The Making of Bispecific Antibodies. MAbs 2017, 9, 182-212. [CrossRef]

162. Topp, M.S.; Duell, J.; Zugmaier, G.; Attal, M.; Moreau, P.; Langer, C.; Krönke, J.; Facon, T.; Salnikov, A.V.; Lesley, R.; et al. Anti-B-Cell Maturation Antigen BiTE Molecule AMG 420 Induces Responses in Multiple Myeloma. JCO 2020, 38, 775-783. [CrossRef]

163. Verkleij, C.P.M.; Frerichs, K.A.; Broekmans, M.; Absalah, S.; Maas-Bosman, P.W.C.; Kruyswijk, S.; Nijhof, I.S.; Mutis, T.; Zweegman, S.; van de Donk, N.W.C.J. T-Cell Redirecting Bispecific Antibodies Targeting BCMA for the Treatment of Multiple Myeloma. Oncotarget 2020, 11, 4076-4081. [CrossRef]

164. Frerichs, K.A.; Broekmans, M.E.C.; Marin Soto, J.A.; van Kessel, B.; Heymans, M.W.; Holthof, L.C.; Verkleij, C.P.M.; Boominathan, R.; Vaidya, B.; Sendecki, J.; et al. Preclinical Activity of JNJ-7957, a Novel BCMA $\times$ CD3 Bispecific Antibody for the Treatment of Multiple Myeloma, Is Potentiated by Daratumumab. Clin. Cancer Res. 2020, 26, 2203. [CrossRef]

165. Cho, S.-F.; Lin, L.; Xing, L.; Liu, J.; Yu, T.; Wen, K.; Hsieh, P.; Munshi, N.; Anderson, K.; Tai, Y.-T. Anti-BCMA BiTE ${ }^{\circledR}$ AMG 701 Potently Induces Specific T Cell Lysis of Human Multiple Myeloma (MM) Cells and Immunomodulation in the Bone Marrow Microenvironment. Blood 2018, 132, 592. [CrossRef]

166. Li, J.; Stagg, N.J.; Johnston, J.; Harris, M.J.; Menzies, S.A.; DiCara, D.; Clark, V.; Hristopoulos, M.; Cook, R.; Slaga, D.; et al. Membrane-Proximal Epitope Facilitates Efficient T Cell Synapse Formation by Anti-FcRH5/CD3 and Is a Requirement for Myeloma Cell Killing. Cancer Cell 2017, 31, 383-395. [CrossRef] [PubMed]

167. Schwartz, M.; Damon, L.E.; Jeyakumar, D.; Costello, C.L.; Tzachanis, D.; Schiller, G.J.; Reiner, J.; Wieduwilt, M.J. Blinatumomab in Combination with Pembrolizumab Is Safe for Adults with Relapsed or Refractory B-Lineage Acute Lymphoblastic Leukemia: University of California Hematologic Malignancies Consortium Study 1504. Blood 2019, 134, 3880. [CrossRef]

168. Correnti, C.E.; Laszlo, G.S.; de van der Schueren, W.J.; Godwin, C.D.; Bandaranayake, A.; Busch, M.A.; Gudgeon, C.J.; Bates, O.M.; Olson, J.M.; Mehlin, C.; et al. Simultaneous Multiple Interaction T-Cell Engaging (SMITE) Bispecific Antibodies Overcome Bispecific T-Cell Engager (BiTE) Resistance via CD28 Co-Stimulation. Leukemia 2018, 32, 1239-1243. [CrossRef] [PubMed]

169. Wu, L.; Seung, E.; Xu, L.; Rao, E.; Lord, D.M.; Wei, R.R.; Cortez-Retamozo, V.; Ospina, B.; Posternak, V.; Ulinski, G.; et al. Trispecific Antibodies Enhance the Therapeutic Efficacy of Tumor-Directed T Cells through T Cell Receptor Co-Stimulation. Nat. Cancer 2020, 1, 86-98. [CrossRef]

170. El-Murr, N.; Henry, C.; Francesconi, E.; Attenot, F.; Virone-Oddos, A.; Vidard, L.; Wu, L.; Yang, Z.-Y.; Chiron, M. Abstract 5641: CD28 Expression on Multiple Myeloma Cells Enhances the Cytotoxic Activity of CD38/CD28xCD3 Trispecific T Cell Engager. Cancer Res. 2020, 80, 5641. [CrossRef]

171. Banaszek, A.; Bumm, T.G.P.; Nowotny, B.; Geis, M.; Jacob, K.; Wölfl, M.; Trebing, J.; Kucka, K.; Kouhestani, D.; Gogishvili, T.; et al. On-Target Restoration of a Split T Cell-Engaging Antibody for Precision Immunotherapy. Nat. Commun. 2019, $10,5387$. [CrossRef]

172. Weidanz, J. Targeting Cancer with Bispecific Antibodies. Science 2021, eabg5568. [CrossRef] 
173. Hsiue, E.H.-C.; Wright, K.M.; Douglass, J.; Hwang, M.S.; Mog, B.J.; Pearlman, A.H.; Paul, S.; DiNapoli, S.R.; Konig, M.F.; Wang, Q.; et al. Targeting a Neoantigen Derived from a Common TP53 Mutation. Science 2021, eabc8697. [CrossRef]

174. Gantke, T.; Reusch, U.; Kellner, C.; Ellwanger, K.; Fucek, I.; Weichel, M.; Kerber, A.; Peipp, M.; Treder, M. AFM26 Is a Novel, Highly Potent BCMA/CD16A-Directed Bispecific Antibody for High Affinity NK-Cell Engagement in Multiple Myeloma. JCO 2017, 35, 8045. [CrossRef]

175. Gantke, T.; Weichel, M.; Herbrecht, C.; Reusch, U.; Ellwanger, K.; Fucek, I.; Eser, M.; Müller, T.; Griep, R.; Molkenthin, V.; et al. Trispecific Antibodies for CD16A-Directed NK Cell Engagement and Dual-Targeting of Tumor Cells. Protein Eng. Des. Sel. 2017, 30, 673-684. [CrossRef] [PubMed]

176. Bluming, A.Z.; Ziegler, J.L. REGRESSION OF BURKITT'S LYMPHOMA IN ASSOCIATION WITH MEASLES INFECTION. Lancet 1971, 298, 105-106. [CrossRef]

177. Taqi, A.M.; Abdurrahman, M.B.; Yakubu, A.M.; Fleming, A.F. Regression of Hodgkin's Disease After Measles. Lancet 1981, 317, 1112. [CrossRef]

178. Coffey, M.C.; Strong, J.E.; Forsyth, P.A.; Lee, P.W.K. Reovirus Therapy of Tumors with Activated Ras Pathway. Science 1998, 282, 1332. [CrossRef]

179. Ong, H.T.; Timm, M.M.; Greipp, P.R.; Witzig, T.E.; Dispenzieri, A.; Russell, S.J.; Peng, K.-W. Oncolytic Measles Virus Targets High CD46 Expression on Multiple Myeloma Cells. Exp. Hematol. 2006, 34, 713-720. [CrossRef]

180. Meyers, D.E.; Thakur, S.; Thirukkumaran, C.M.; Morris, D.G. Oncolytic Virotherapy as an Immunotherapeutic Strategy for Multiple Myeloma. Blood Cancer J. 2017, 7, 640. [CrossRef]

181. Calton, C.M.; Kelly, K.R.; Anwer, F.; Carew, J.S.; Nawrocki, S.T. Oncolytic Viruses for Multiple Myeloma Therapy. Cancers 2018, 10, 198. [CrossRef]

182. Packiriswamy, N.; Upreti, D.; Zhou, Y.; Khan, R.; Miller, A.; Diaz, R.M.; Rooney, C.M.; Dispenzieri, A.; Peng, K.-W.; Russell, S.J. Oncolytic Measles Virus Therapy Enhances Tumor Antigen-Specific T-Cell Responses in Patients with Multiple Myeloma. Leukemia 2020, 34, 3310-3322. [CrossRef] [PubMed]

183. Dingli, D.; Peng, K.-W.; Harvey, M.E.; Greipp, P.R.; O'Connor, M.K.; Cattaneo, R.; Morris, J.C.; Russell, S.J. Image-Guided Radiovirotherapy for Multiple Myeloma Using a Recombinant Measles Virus Expressing the Thyroidal Sodium Iodide Symporter. Blood 2004, 103, 1641-1646. [CrossRef] [PubMed]

184. Carlson, S.K.; Classic, K.L.; Hadac, E.M.; Dingli, D.; Bender, C.E.; Kemp, B.J.; Russell, S.J. Quantitative Molecular Imaging of Viral Therapy for Pancreatic Cancer Using an Engineered Measles Virus Expressing the Sodium-Iodide Symporter Reporter Gene. AJR Am. J. Roentgenol 2009, 192, 279-287. [CrossRef]

185. Dispenzieri, A.; Tong, C.; LaPlant, B.; Lacy, M.Q.; Laumann, K.; Dingli, D.; Zhou, Y.; Federspiel, M.J.; Gertz, M.A.; Hayman, S.; et al. Phase I Trial of Systemic Administration of Edmonston Strain of Measles Virus Genetically Engineered to Express the Sodium Iodide Symporter in Patients with Recurrent or Refractory Multiple Myeloma. Leukemia 2017, 31, 2791-2798. [CrossRef] [PubMed]

186. Cook, J.; Peng, K.W.; Geyer, S.M.; Ginos, B.F.; Dueck, A.C.; Packiriswamy, N.; Zhang, L.; Brunton, B.; Balakrishnan, B.; Witzig, T.E.; et al. Clinical Activity of Systemic VSV-IFN $\beta$-NIS Oncolytic Virotherapy in Patients with Relapsed Refractory T-Cell Lymphoma. JCO 2021, 39, 2500. [CrossRef] 